\title{
Fertility of nationals and foreigners in Spain, Italy, and Greece during and after the economic recession and refugee crisis
}

\author{
Fecundidad de nacionales y extranjeros en España, Italia y Grecia \\ durante y después de la recesión económica y la crisis de los refugiados
}

\author{
Byron Kotzamanis $^{1}$ [D
}

\begin{abstract}
This article provides an overview of trends in fertility of foreign and national women in Greece, Spain, and Italy during the last decade and before the Covid pandemic. It focuses on the fertility of foreigners and compares this with that of 'nationals'. The main analysis focuses on a period marked, firstly, by the economic recession and stagnation, and then by the recent wave of the 'refugee crisis'. Foreigner fertility in the three south Mediterranean countries differs significantly from that of nationals, with the former having higher fertility rates and lower mean age at childbearing. However, although foreigners make a large contribution to births, their impact on period fertility (total fertility rate or TFR) is limited. At the same time, although the fertility of both groups decreased during the first years of the recession, foreigner TFRs fell faster in both absolute and relative terms in Italy and Greece. However, after 2014, the foreigner period fertility among the three countries differs as a relative stabilisation is observed in Spain and Italy, while indicators rise in Greece. This divergence is due to the various composition changes in the settled after-2014 foreigners in the three countries and the strong recovery of foreigner births in Greece (as fertility in Greece was much more affected by the recession).
\end{abstract}

Keywords: Spain; Italy; Greece; foreigners; nationals; period fertility; economic crisis; refugee crisis.

\section{Resumen}

Este artículo ofrece una visión general de las tendencias de la fecundidad de las mujeres extranjeras y nacionales en Grecia, España e Italia durante la última década y antes de la pandemia del Covid. Se centra especialmente en la fecundidad de las extranjeras y la compara con la de las "nacionales". El análisis principal se centra en un periodo marcado, primero, por la recesión y el estancamiento económico, y luego, por la reciente ola de la "crisis de refugiados". La fecundidad de los extranjeros en los tres países del sur del Mediterráneo difiere significativamente de la de los nacionales, ya que los primeros tienen tasas de fecundidad más altas y una edad media de maternidad más baja. Sin embargo, aunque los extranjeros contribuyen en gran medida a los nacimientos, su impacto en la fecundidad periódica (TFR) es limitado. Al mismo tiempo, aunque la fecundidad de ambos grupos disminuyó durante los primeros años de la recesión, la TFR de los extranjeros cayó más rápidamente en términos absolutos y relativos en Italia y Grecia. Sin embargo, a partir de 2014, la fecundidad del periodo de los extranjeros difiere entre los tres países, ya que en España e Italia se observa una estabilización relativa, mientras que los indicadores aumentan en Grecia. Esta divergencia se debe a los diferentes cambios de composición de los extranjeros asentados después de 2014 en los tres países estudiados y a la fuerte recuperación de los nacimientos de extranjeros en Grecia, ya que su fecundidad se vio mucho más afectada por la recesión.

Palabras clave: España; Italia; Grecia; extranjeros; nacionales; fecundidad periódica; crisis económica; crisis de refugiados.

1 Laboratory of Demographic and Social Analyses (Lads), University of Thessaly, Greece. bkotz@uth.gr 


\section{Introduction}

European post-war populations are characterized by an increasing share of immigrants and their descendants, and the recent "refugee crisis" has significantly affected migration streams and foreign settlers' profile in some European countries (Arslan et al., 2014 \& 2016; King \& Okólski, 2019; OECD, 2019). Especially, Spain, Italy and Greece, traditionally emigration countries before 1980, received thousands of economic immigrants during 1990 and 2010 (Arango, 2000; Cornelius, 2004; Bonifazi, 2013; Bonifazi \& Strozza, 2017; Strozza, \& De Santis, 2017; Kotzamanis \& Karkanis, 2018; Colombo \& Dalla Zuanna, 2019), a verified fact by the last censuses as well as by the population estimations of their Statistical Authorities (Table 1).

Table 1. Spain, Italy, Greece, total population, nationals \& foreigners (1991-2019)

\begin{tabular}{|c|c|c|c|c|c|}
\hline & Total (million) & $\begin{array}{l}\text { Nationals } \\
\text { (million) }\end{array}$ & $\begin{array}{c}\text { Foreigners } \\
\text { (million) }\end{array}$ & Nationals, \% & Foreigners, \% \\
\hline \multicolumn{6}{|l|}{ SPAIN } \\
\hline $1991^{*}$ & 38,872 & 38,519 & 0,353 & 99.1 & 0.9 \\
\hline $2001^{*}$ & 40,847 & 39,275 & 1,572 & 96.2 & 3.8 \\
\hline $2009 * *$ & 46,746 & 41,097 & 5,649 & 87.9 & 12.1 \\
\hline $2011^{*}$ & 46,816 & 41,564 & 5,252 & 88.8 & 11.2 \\
\hline $2015 * *$ & 46,624 & 4,1895 & 4,729 & 89.9 & 10.1 \\
\hline $2019 * *$ & 47,026 & 41,989 & 50,37 & 89.3 & 10.7 \\
\hline \multicolumn{6}{|l|}{ ITALY } \\
\hline $1991 *$ & 56,778 & 56,422 & 0,356 & 99.4 & 0.6 \\
\hline $2001^{*}$ & 56,996 & 55,661 & 1,334 & 97.7 & 2.3 \\
\hline $2009 * *$ & 59,000 & 55,598 & 3,402 & 94.2 & 5.8 \\
\hline $2011^{*}$ & 59434 & 55,406 & 4,027 & 93.2 & 6.8 \\
\hline $2015 * *$ & 60,796 & 55,782 & 5,014 & 91.8 & 8.2 \\
\hline $2019 * *$ & 60,360 & 55,105 & 5,255 & 91.3 & 8.7 \\
\hline \multicolumn{6}{|c|}{ GREECE } \\
\hline $1991 *$ & 10,260 & 10,093 & 0,166 & 98.4 & 1.6 \\
\hline $2001^{*}$ & 10,934 & 10,172 & 0,762 & 93.0 & 7.0 \\
\hline $2009 * *$ & 11,094 & 10,167 & 0,927 & 91.6 & 8.4 \\
\hline $2011^{*}$ & 10,816 & 9,904 & 0,912 & 91.6 & 8.4 \\
\hline $2015 * *$ & 10,858 & 10,036 & 0,822 & 92.4 & 7.6 \\
\hline $2019 * *$ & 10,725 & 9,893 & 0,832 & 92.2 & 7.8 \\
\hline
\end{tabular}

* Population and housing censuses data, usual residents

** Estimated population at 1.1. Year

Source: ELSTAT (2020a \& b), INE (2020), ISTAT (2020), EUROSTAT (2020). Own elaboration

The official statistics in all European countries have been collecting more and more information concerning immigrants and their descendants, and immigrant fertility has emerged as an important research topic during the last two decades, especially in countries having long migration tradition (Sobotka, 2008; Kulu \& González-Ferrer, 2014; Adserà \& Ferrer, 2015; Kulu et al., 2015; Kulu, Milewski, Hannemann, \& Mikolai, 2019). A part of the literature is focused on period fertility migrants' indicators and their impact on overall TFR ${ }^{2}$, and another part on the quantum of fertility, using summary measures. Yet, during the last two decades the largest part of research has been focusing on fertility behavior at individual level, applying a life-course perspective to family formation and subsequent immigrant births ${ }^{3}$.

While most of the studies focus on Western and Northern European countries, recently, some of them integrate - or focus exclusively - on the analysis of migrant fertility models in Southern European coun-

2 The majority of these works underlines both the heterogeneity in the fertility of various migrant groups and the tendency for a gradual convergence of migrant period indicators with nationals/natives. Especially, with some exceptions (women from Turkey, Maghreb, and African countries), in a considerable number of studies, the fertility of migrant and their daughters do not deviate much from that of the native population as they gradually adjust their reproductive behaviour and adopt the fertility norms and practices of the host countries. 3 Most of them aim to test one or several hypotheses on migrant fertility (assimilation, adaption, selectivity, disruption). 
tries, becoming host countries after 1990. Thus, some comparative studies have been examining migrant fertility over the last years (Sobotka, 2008 \& 2017; Kulu \& González-Ferrer, 2014; Kulu, et al., 2015 \& 2019; Bagavos, 2019; Mussino \& Cantali, 2020).

At the same time, recognizing the potentially rejuvenating effect of increased migration flows combined with higher migrant fertility in countries with extremely low fertility rates as Spain and Italy, scholars have started to investigate the fertility and childbearing behaviour of migrant women ${ }^{4}$. In Italy, the first studies appeared at the end of the '90s - the beginning of 2000 (Natale \& Strozza, 1997; Guerrizio, Sonnino $\&$ Strozza, 2003) and attention has been paid more and more to the impact of migrant fertility on the structure and population dynamics, with emphasis on the TFR (Strozza, Labadia \& Ferrara, 2007; De Bartolo \& Stranges, 2008; Mussino, Iaccarino, Prati \& Strozza, 2009; Mussino, Gabrielli, Paterno, Strozza \& Terzera, 2012; Ortensi, 2012; Mussino \& Van Raalte, 2013; Giannantoni \& Strozza, 2015).

More recent works (Mussino \& Strozza, 2012a \& b; Ortensi, 2015; Mussino, Gabrielli, Paterno, Stroza \& Terzera, 2015; Giannantoni, Mussino, Gabrielli \& Strozza, 2016; Giannantoni, Ortensi, Strozza \& Gabrielli, 2019; Vitali \& Billari, 2017; Mussino, Gabrielli, Ortensi \& Strozza, 2020; Impicciatore, Gabrielli \& Paterno, 2020) rely on new data and approaches (the post-migration fertility analysis, migration patterns, migrant fertility from a spatial perspective, etc.).

In Spain, a country receiving migrants from Latin America par excellence, having at the same time a more open policy of family reunification and acquisition of nationality especially, foreigners from Latin American countries (González-Ferrer \& Trilla, 2011; Domingo \& Ortega-Rivera, 2015), the first studies, as in Italy, focus on the impact of immigration on the structure and population dynamics using basic fertility indices (Delgado \& Zamora López, 2003 \& 2006; Devolder, 2006; Escribano, 2006; Devolder \& Treviño, 2007). Nevertheless, subsequently, Spanish demographers' work has focused more and more on the differences in fertility between nationals/natives and foreigners/non-natives at national and regional levels, using censuses, registers, and survey data (Roig Vila \& Castro-Martín, 2007a \& b; Hierro-Hernández \& Torre-Fernández, 2010; Castro-Martín \& Rosero-Bixby, 2011; Devolder \& Bueno, 2011; Del Rey \& Parrado, 2012; Bueno \& Devolder, 2012; Del Rey \& Grande, 2015; González-Ferrer, Castro-Martín \& Kraus, 2015; González-Ferrer, Castro-Martín, Kraus \& Eremenko, 2017; Kraus \& Castro-Martín, 2017). Nationality or country of birth, duration of stay and age at the time of arrival, socio-demographic characteristics, and birth parity are increasingly considered to detect patterns consistent with both the adaptation, selectivity, socialization, and the disruption hypothesis. In these works, we observe a much slower assimilation of the Maghreb and African origin immigrants into the mainstream fertility behaviour (as in Italy), whereas the convergence is observed for the 1.5 generation of Latin American immigrants.

Unlike Spain and Italy, in Greece, foreign/immigrant fertility has relatively been poorly researched, and few articles have investigated this issue (Kotzamanis \& Sofianopoulou, 2008; Bagavos, Tsimos \& Verropoulou , 2008; Tsimbos, 2008; Sofianopoulou \& Siapati, 2009; Bagavos, Verropoulou \& Tsimbos, 2018; Kotzamanis \& Karkanis, 2019) focusing mainly on period fertility migrant indicators and their impact on overall TFR. At the same time, it must be noted that, to date, comparative studies that have focused particularly on the fertility trends of nationals and foreigners in the south European countries or on the impacts of the recent recession and the "refugee crisis" on the fertility of these two groups are rare (Gabrielli, Paterno \& Strozza, 2007; Ferrara, Giorgi, Mamolo \& Strozza, 2009; Mamolo \& Ferrara, 2009; Barbieri, Bozzon, Scherer, Grotti \& Lugo, 2015; Graham, Sabater \& Fiori, 2016).

This article intends to fill partially this gap of the literature by estimating period fertility levels and trends between foreigners and nationals in Greece, Spain, and Italy for 2007-2018. The main questions we will try to answer are: i) What was the impact of the recent recession on the fertility of those two groups?; ii) What is the reason for the different trends of foreign fertility in Greece in relation to that in Italy and Spain after 2014?

\section{Methodology}

\subsection{Data and concepts (Foreigners' fertility versus migrant fertility)}

Our work gives an answer to the above two questions using datasets on births by age as well as on population estimates by gender $\&$ age for nationals and foreigners provided from the Hellenic Statistical

\footnotetext{
4 In these countries, a large part of the public opinion and the mass media after 2000 began, due to the increasing number of foreigners' births, to express the fear that their national identity will soon be threatened.
} 
Authority (ELSTAT, 2020b \& c), Eurostat (EUROSTAT, 2020), INE (2020) and ISTAT (2020). These data are used to calculate age-specific fertility rates as well as the period $\mathrm{TFR}^{5}$ for resident population (overall, "nationals" and "foreigners") ${ }^{6}$. These indicators enable us to examine the foreigners' contribution to overall fertility during the past decade and interpret its fluctuations. Yet, it must be noted that our comparative analysis is hampered by limited data availability, as estimations on the age distribution of foreigners and nationals have been available annually only after 2008 in Greece, 1995 in Spain and 1994 in Italy, while the repartition of births per age and nationality varies (from 2004 in Greece, 1996 in Spain and 1995 in Italy)7.

In the literature, most studies on the same topic concern the distinction between "natives" and "non-natives" (women born abroad), and many authors like Sobotka (2008 \& 2010) consider that the distinction between nationals and foreigners is problematic as: i) many initially foreign women obtain citizenship after a period of stay; ii) some women born to parents with foreign nationality may themselves retain foreign nationality even if they were born and subsequently live in the country. They also claim that this is why fertility rates of women with foreign nationality have to be interpreted as a gross approximation of migrant fertility and with caution. These arguments are reliable concerning European host countries with a long migratory tradition and favourable legislation on citizenship acquisition. In particular, regarding Italy and Greece, which have become host countries mainly in 90's and do not have an open-door policy on citizenship, are not so valid ${ }^{8}$. In fact, estimations based on natives/non-natives pose more methodological problems, since the first category excludes numerous nationals born abroad.

\subsection{The wider environment}

The period under study presents particular interest, as, for 2009-2018 decade, two significant events took place, with clearly different intensity in the three countries, i.e.

a) The recession, the longest and the most severe since the Depression of the 1930s which, hit hard south-European households and had an impact on family dynamics - especially on fertility -, as in almost all the developed countries (Sobotka, Skirbekk \& Philipov, 2011; Kreyenfeld, Anderson \& Pailhe, 2012; Goldstein, Kreyenfeld, Jasilioniene \& Orsal, 2013; Bellido \& Marcen, 2016; Comolli, 2017; Ayllon, 2019; Alderotti, Mussino \& Comolli, 2019; Matysiak, Bignoli \& Sobotlka, 2020). This recession, which hit Greece much harder than Spain and Italy (OECD, 2014; European Commission 2016-2019; Pissarides, Vafianos, Vettas \& Megir, 2020), had also impacts on migration flows in the southern European countries: it caused the departure of part of the population of reproductive age, both nationals and foreigners who had settled in these countries during the previous decades (Larramona, 2013; Recaño, Roig \& De Miguel, 2015; Labrianidis \& Pratsinakis, 2016; Cerrutti \& Maguid, 2016; Bayona-i-Carrasco, Thiers Quintana \& Avila-Tàpies, 2017; Bermudez \& Brey, 2017; Bonifazi \& Strozza, 2017; Tintori \& Romei, 2017; Strozza \& De Santis, 2017; Kotzamanis, 2018; Kotzamanis \& Karkanis, 2018; Prieto-Rosas \& Quintero-Lesmes, 2018; Colombo \& Dalla Zuanna, 2019).

b) The after 2014 period ("Refugee crisis"), as almost 3 million persons entered Italy, Spain, and Greece illegally (Kotzamanis, Carella, Duquenne \& Pappas, 2020). A part of these migrants no originate from ex-socialist countries could not leave and was obliged to stay in the three under consideration countries. At the same time, the distribution by nationality of these new incomers was different, especially in Greece, from that in the near past (EUROSTAT, 2020) ${ }^{9}$.

5 We must, however, note that TFR may not always be the best measure for studying immigrant fertility (Burkimsher, Rossier \& Wanner 2018), especially when the aim is to make inferences about differences between immigrants and non-immigrants (foreigners and nationals) in their fertility quantum. The complementary visual method e.g. proposed by Tønnessen \& Wilson (2020) requests data which are not available in the majority of European countries.

6 'Nationals': women having country nationality. They may have had this nationality from birth or acquired it during their lifetime through naturalization. 'Foreigners': women with any nationality, not including the nationality of the country under consideration. They may or may not have been born in this country.

7 Fertility measures of the foreign-born population in the three under consideration countries are not available, which in any case precludes a comparative analysis. It should also be noted that almost all births during this period come from women belonging to the first and 1.5 generation (women who arrived at age 0 - 15 years) as most of their descendants are not yet at reproductive age. Due to this, it is impossible to anticipate how they will behave in terms of childbearing.

8 In Italy and Greece, in the 2011 census, women 15-49 years holding citizenship of these countries and born abroad constituted 3\% and $7 \%$ respectively in the total of women at reproductive age. A small part of this age group was foreigners that acquired citizenship after their birth and registered as nationals at childbearing. Thus, if we applied the criterion of the country of birth in Greece and Italy, the largest part of citizens 15-49 of age born abroad would be considered 'migrants'.

9 In this country, which has been the major entry gate for persons entering the EU space using the Mediterranean route, almost a tripling of residents coming from Medium and Low Development countries (MDC/LDC) is recorded between 1/1/2015 and 1/1/2019, together with a considerable increase in their relative proportion of the total of foreigners (from 13.5 to $29.0 \%$ ). Even though the same trends, in broad terms, are also recorded in Italy, the subsequent changes were minor, while in Spain which, since the end of the 1990s, has been receiving immigrants mainly from Latin America and, secondarily, from Maghreb (Morocco), the part of those coming from LDC/ MDC countries during the last decade has slightly changed (Table 4). 


\section{Results}

\subsection{Foreigners in South Europe, a large contribution to births}

Foreign women in Spain, Italy, and Greece comprise 8-15\% of the reproductive age population (Table 2). These percentages and their variations differ during the last decade. While in Spain and Greece minor changes are observed, the \% increase continuously in Italy (+4.8 points between 2007 and 2018). These different trends reflected partially in the changes in foreigners' participation in births, as their percentages, higher than the relative proportion on reproductive age population ${ }^{10}$, present minor fluctuations in Spain, increase continuously in Italy, and follow a declining course until 2014 in Greece.

Table 2. Women 15-49 years by citizenship (country/foreigner citizens) at the middle of the year

\begin{tabular}{|l|r|r|r|r|r|r|r|r|r|r|r|r|r|}
\hline & 2007 & 2008 & 2009 & 2010 & 2011 & 2012 & 2013 & 2014 & 2015 & 2016 & 2017 & 2018 \\
\hline
\end{tabular}

\begin{tabular}{|c|c|c|c|c|c|c|c|c|c|c|c|c|}
\hline $\begin{array}{l}W \text { o } m \text { e } \\
15-49 \text { years }\end{array}$ & & & & & & & & & & & & \\
\hline All (million) & $13,950.0$ & $10,009.8$ & $13,722.0$ & $13,661.9$ & $13,576.8$ & $13,482.2$ & $13,496.1$ & $13,458.6$ & $13,262.9$ & $13,052.6$ & $12,841.9$ & $12,634.5$ \\
\hline Nationals (\%) & 92.10 & 90.92 & 90.88 & 90.23 & 89.75 & 89.27 & 88.39 & 87.70 & 87.51 & 87.47 & 87.41 & 87.28 \\
\hline Foreigners (\%) & 7.90 & 9.08 & 9.12 & 9.77 & 10.25 & 10.73 & 11.61 & 12.30 & 12.49 & 12.53 & 12.59 & 12.72 \\
\hline
\end{tabular}

GREECE

\begin{tabular}{|c|c|c|c|c|c|c|c|c|c|c|}
\hline $\begin{array}{l}W \text { o m e r } \\
15-49 \text { years }\end{array}$ & & & & & & & & & & \\
\hline All (million) & $2,649.0$ & $2,629.0$ & $2,600.8$ & $2,563.2$ & $2,522.5$ & $2,484.0$ & $2,445.1$ & $2,407.0$ & $2,370.1$ & $2,332.0$ \\
\hline Nationals (\%) & 88.41 & 88.48 & 88.59 & 88.76 & 88.99 & 89.26 & 89.58 & 89.85 & 90.13 & 90.39 \\
\hline Foreigners (\%) & 11.59 & 11.52 & 11.41 & 11.24 & 11.01 & 10.74 & 10.42 & 10.15 & 9.87 & 9.61 \\
\hline
\end{tabular}

Source: EUROSTAT (2020), INE (2020), ISTAT (2020), ELSTAT (2020b \& c). Own elaboration

\subsection{Yet a limited impact on overall TFR and on the mean age at childbearing}

Our analyses show that, as expected, foreigners' TFRs for 2009-2018 in Spain, Italy, and Greece are higher than that of the nationals, and differences among these countries are significant (Table $3 \&$ Figure 1). In Spain, foreign women give birth to 0.30-0.43 children more than nationals, and the differences between the two groups' TFR's do not present significant fluctuations for 2009-2018. The same does not apply to Italy and Greece. In these countries, the range is wider, from 1.23 to 0.71 in the former, from 1.14 to 0.39 children in the latter. In Greece especially, any trends towards convergence of TFR halted in 2014, and the differences have increased thereafter. Conversely, the mean age gap in childbearing between foreigners and nationals differs slightly among the three countries. Whether the increasing trends of this indicator in Spain and Italy do not differ between the two groups, on the contrary, in Greece, the mean age after 2014 slightly decreases as far as foreigners are concerned and continue to increase for nationals, exceeding 32 years in 2018 (Table $3 \&$ Figure 2).

In fact, until 2018, foreigners' net contribution to the overall TFR in absolute and relative terms is limited as they increased this indicator (i) from 0.07 to 0.04 children/woman in Spain, 0.13-0.08 in Italy, and 0.12-0.034 respectively in Greece in relative terms, and, (ii) $5.5-3.5 \%, 8.5-6.0 \%$ and $8.3-2.6 \%$ respectively in relative values from (Figure 3).

10 This discrepancy exists, since births are the products of two independent components: the number of women as well as their distribution per age and their fertility. 
Table 3. Key data on TRF by citizenship (country/foreigner citizens) in Spain, Italy and Greece and their relative impact on fertility and number of births

\begin{tabular}{|c|c|c|c|c|c|c|c|c|c|c|c|c|}
\hline & 2007 & 2008 & 2009 & 2010 & 2011 & 2012 & 2013 & 2014 & 2015 & 2016 & 2017 & 2018 \\
\hline \multicolumn{13}{|l|}{ SPAIN } \\
\hline Births of foreigners, $\%$ & 18.79 & 20.65 & 20.55 & 20.36 & 19.30 & 19.05 & 18.39 & 17.60 & 17.62 & 18.20 & 19.02 & 20.77 \\
\hline TFR - Foreigners & 1.756 & 1.860 & 1.715 & 1.690 & 1.592 & 1.570 & 1.532 & 1.611 & 1.662 & 1.710 & 1.699 & 1.576 \\
\hline TFR - Nationals & 1.314 & 1.368 & 1.316 & 1.310 & 1.302 & 1.282 & 1.235 & 1.277 & 1.285 & 1.280 & 1.246 & 1.193 \\
\hline TFR - Total & 1.384 & 1.454 & 1.388 & 1.378 & 1.351 & 1.328 & 1.279 & 1.323 & 1.335 & 1.337 & 1.308 & 1.251 \\
\hline Difference TFR F-N & 0.442 & 0.492 & 0.399 & 0.380 & 0.290 & 0.288 & 0.297 & 0.334 & 0.377 & 0.430 & 0.453 & 0.383 \\
\hline Difference TFR T-N & 0.070 & 0.086 & 0.072 & 0.068 & 0.049 & 0.046 & 0.044 & 0.046 & 0.050 & 0.057 & 0.062 & 0.058 \\
\hline $\begin{array}{l}\text { Relative diff (\%) } \\
\text { TFR T - TFR N/TFR T*100 }\end{array}$ & 5.058 & 5.915 & 5.187 & 4.935 & 3.627 & 3.464 & 3.440 & 3.477 & 3.745 & 4.263 & 4.740 & 4.636 \\
\hline Mean age at childbearing -Total & 30.84 & 30.83 & 31.02 & 31.19 & 31.43 & 31.56 & 31.67 & 31.77 & 31.89 & 31.99 & 32.07 & 32.17 \\
\hline Mean age at childbearing - Nationals & 31.47 & 31.52 & 31.68 & 31.83 & 32.02 & 32.14 & 32.20 & 32.26 & 32.36 & 32.47 & 32.56 & 32.69 \\
\hline Mean age at childbearing - Foreigners & 28.14 & 28.19 & 28.50 & 28.71 & 28.88 & 28.96 & 29.17 & 29.32 & 29.46 & 29.58 & 29.69 & 29.92 \\
\hline Mean age at childbearing F-N & -3.33 & -3.33 & -3.18 & -3.12 & -3.14 & -3.18 & -3.03 & -2.94 & -2.90 & -2.89 & -2.87 & -2.77 \\
\hline Mean age at childbearing T-N & -0.63 & -0.69 & -0.66 & -0.64 & -0.59 & -0.58 & -0.53 & -0.49 & -0.47 & -0.48 & -0.49 & -0.52 \\
\hline \multicolumn{13}{|l|}{ ITALY } \\
\hline Births of foreigners, $\%$ & 14.62 & 15.92 & 17.11 & 17.67 & 18.38 & 19.03 & 19.22 & 19.37 & 19.41 & 19.70 & 20.03 & 20.16 \\
\hline TFR - Foreigners & 2.415 & 2.330 & 2.558 & 2.441 & 2.377 & 2.335 & 2.110 & 1.987 & 1.950 & 1.977 & 1.988 & 1.945 \\
\hline TFR - Nationals & 1.281 & 1.318 & 1.332 & 1.339 & 1.319 & 1.308 & 1.283 & 1.279 & 1.264 & 1.254 & 1.234 & 1.205 \\
\hline TFR - Total & 1.401 & 1.448 & 1.451 & 1.456 & 1.437 & 1.428 & 1.384 & 1.365 & 1.344 & 1.337 & 1.318 & 1.287 \\
\hline Difference TFR F-N & 1.134 & 1.012 & 1.226 & 1.102 & 1.058 & 1.027 & 0.827 & 0.708 & 0.686 & 0.723 & 0.754 & 0.740 \\
\hline Difference TFR T-N & 0.120 & 0.130 & 0.119 & 0.117 & 0.118 & 0.120 & 0.101 & 0.086 & 0.080 & 0.083 & 0.084 & 0.082 \\
\hline $\begin{array}{l}\text { Relative difference (\%) } \\
\text { TFR T - TFR N/TFR T*100 }\end{array}$ & 8.565 & 8.978 & 8.201 & 8.036 & 8.212 & 8.403 & 7.298 & 6.300 & 5.952 & 6.208 & 6.373 & 6.371 \\
\hline Mean age at childbearing - Total & 31.04 & 31.07 & 31.13 & 31.23 & 31.33 & 31.37 & 31.45 & 31.50 & 31.63 & 31.73 & 31.84 & 31.95 \\
\hline Mean age at childbearing - Nationals & 31.55 & 31.65 & 31.75 & 31.86 & 31.95 & 31.99 & 32.05 & 32.09 & 32.21 & 32.31 & 32.42 & 32.51 \\
\hline Mean age at childbearing - Foreigners & 27.76 & 27.84 & 27.81 & 28.06 & 28.33 & 28.38 & 28.51 & 28.55 & 28.64 & 28.73 & 28.85 & 29.01 \\
\hline Mean age at childbearing F-N & -3.79 & -3.81 & -3.94 & -3.80 & -3.62 & -3.61 & -3.54 & -3.54 & -3.57 & -3.58 & -3.57 & -3.50 \\
\hline Mean age at childbearing T-N & -0.51 & -0.58 & -0.62 & -0.63 & -0.62 & -0.62 & -0.60 & -0.59 & -0.58 & -0.58 & -0.58 & -0.56 \\
\hline \multicolumn{13}{|l|}{ GREECE } \\
\hline Births of foreigners, $\%$ & 18.13 & 18.41 & 18.84 & 18.66 & 17.68 & 15.34 & 13.91 & 13.14 & 12.91 & 13.59 & 13.92 & 14.20 \\
\hline TFR - Foreigners & & & 2.340 & 2.325 & 2.123 & 1.831 & 1.642 & 1.630 & 1.730 & 2.042 & 2.186 & 2.410 \\
\hline TFR - Nationals & & & 1.377 & 1.361 & 1.294 & 1.283 & 1.250 & 1.261 & 1.285 & 1.317 & 1.276 & 1.269 \\
\hline TFR - Total & 1.409 & 1.498 & 1.501 & 1.482 & 1.394 & 1.344 & 1.290 & 1.295 & 1.322 & 1.375 & 1.344 & 1.347 \\
\hline Difference TFR F-N & & & 0.963 & 0.964 & 0.829 & 0.548 & 0.392 & 0.369 & 0.445 & 0.725 & 0.910 & 1.141 \\
\hline Difference TFR T-N & & & 0.124 & 0.121 & 0.100 & 0.061 & 0.040 & 0.034 & 0.037 & 0.058 & 0.068 & 0.078 \\
\hline $\begin{array}{l}\text { Relative difference } \\
\text { TFR T - TFR N/TFR T*100 }\end{array}$ & & & 8.261 & 8.165 & 7.174 & 4.539 & 3.101 & 2.625 & 2.799 & 4.218 & 5.060 & 5.771 \\
\hline Mean age at childbearing - Total & & & 30.35 & 30.43 & 30.55 & 30.71 & 30.93 & 31.06 & 31.27 & 31.31 & 31.41 & 31.51 \\
\hline Mean age at childbearing - Nationals & & & 31.12 & 31.18 & 31.24 & 31.27 & 31.38 & 31.48 & 31.68 & 31.82 & 31.93 & 32.06 \\
\hline Mean age at childbearing - Foreigners & & & 27.10 & 27.20 & 27.35 & 27.60 & 28.06 & 28.24 & 28.38 & 27.94 & 27.98 & 27.90 \\
\hline Mean age at childbearing F-N & & & -4.02 & -3.98 & -3.89 & -3.67 & -3.32 & -3.24 & -3.30 & -3.88 & -3.95 & -4.16 \\
\hline Mean age at childbearing T-N & & & -0.77 & -0.75 & -0.69 & -0.56 & -0.45 & -0.42 & -0.41 & -0.51 & -0.52 & -0.55 \\
\hline
\end{tabular}

Source: EUROSTAT (2020), INE (2020), ISTAT (2020), ELSTAT (2020b \& c). Own elaboration 
Figure 1. Spain, Italy and Greece, TFR (overall, nationals, foreigners), 2009-2018

Spain

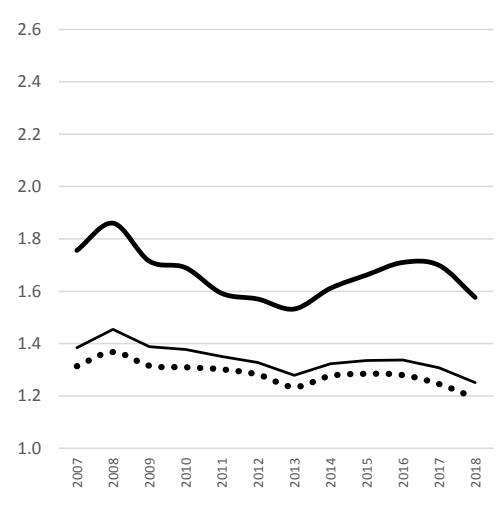

- $\ldots . . \times N$
Italy

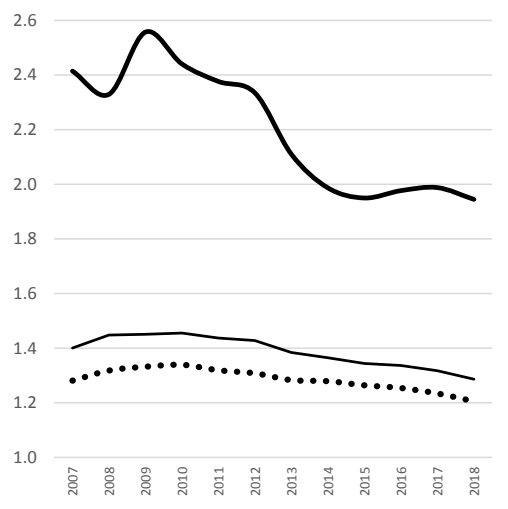

Source: Table 3
Greece
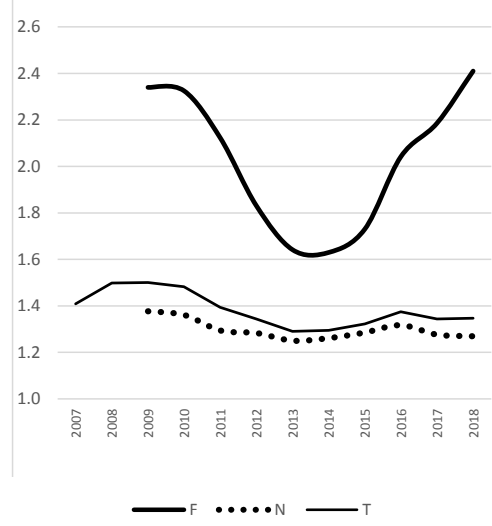

Figure 2. Spain, Italy and Greece, mean age at childbearing (overall, nationals, foreigners), 2009-2018

Spain

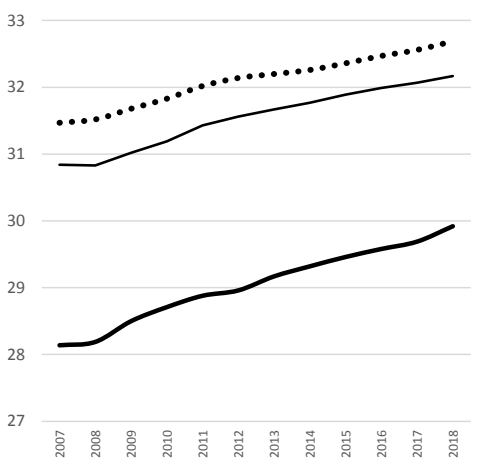

Italy

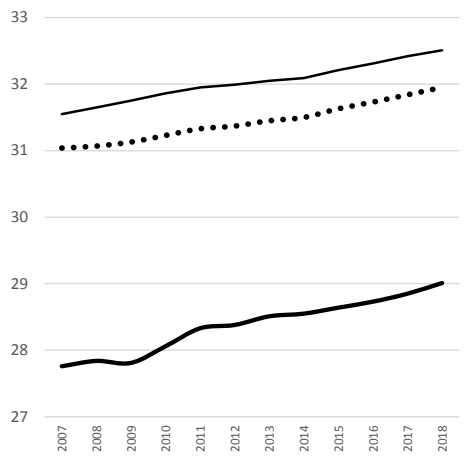

Source: Table 3
Greece

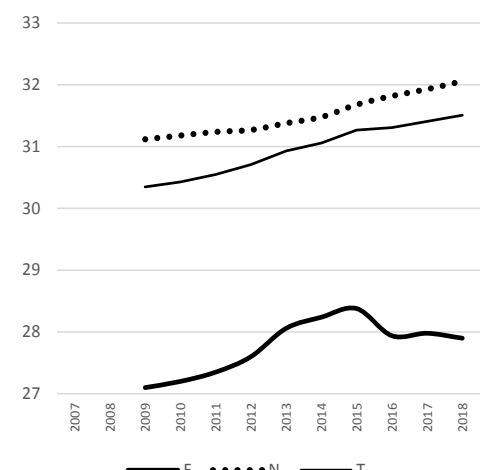

Figure 3. Spain, Italy and Greece, Foreigner s fertility impact on overall TFR (\%)

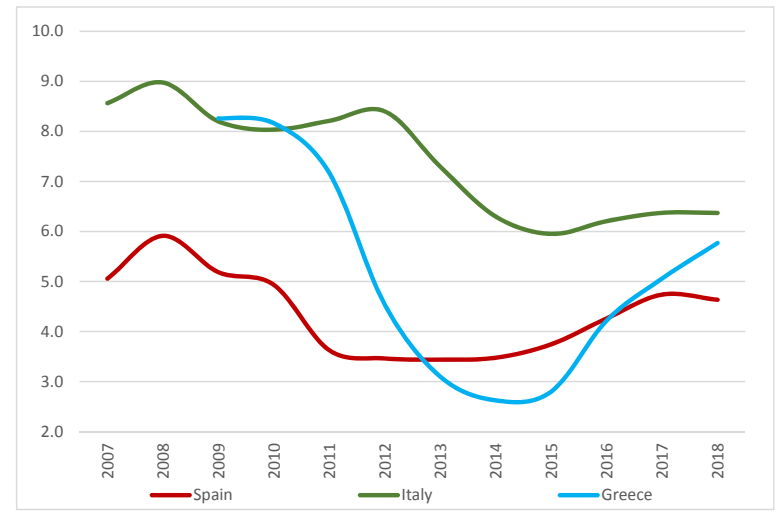

Source: Table 3

At the same time, examinating the absolute and relative annual TFR variations (Figures $4 \& 5$ ), we confirm the specificity of Greece as, in contrast to Spain and Italy: i) the foreigners' TFR declined much faster than those of the nationals between 2009 and 2014, leading to rendering their overall TFR smaller from $8.3 \%$ in 2009 to $2.6 \%$ in 2014; ii) in recent years, TFR evolution between nationals and foreigners is clearly different. 
More to the point, we should bear in mind that foreigners' TFR is the resultant of two discrete women subgroups, i.e citizens from countries (a) having High and Very High Human Development Index (HDC/ VHDC) and (b) with medium (MHDI/MDC) - many Asian countries - and Low High Human Development Index (LHDI/LDC) - almost all-African countries -. The relative proportion of women of these two groups, as aforementioned, was not steady during the period under examination. In Greece especially, part of the foreigners from ex-socialist countries that settled before 2010 were obliged to return to their country of origin or migrate to another EU country, resulting in a decrease in their relative proportion (i.e., the percentage of the total foreign population). At the same time, since the first years of the 2010 decade, and more particularly after 2014, the population of foreigners coming from MDC and LDC countries, in the large majority citizens of Syria, Iraq, Afghanistan, Iran, and Pakistan (Kotzamanis \& Karkanis, 2018; Kotzamanis et al., 2020), increased significantly. Thus, the percentage of foreign women of reproductive age coming from the two last groups, in the total of women $15-49$ years old, doubled between $1 / 12015$ and $1 / 1 / 2019^{11}$. However, the same does not apply to Spain and Italy, where, before 2015, the percentages of women coming from these MDC and LDC countries were rather high $(>25 \%)$, and their variations $(+1.5-+2.0 \%)$ limited (Table 4$)$.

Figure 4. Spain, Italy, Greece, absolute changes in TFR by citizenship (foreigners/nationals, 2009-2018)
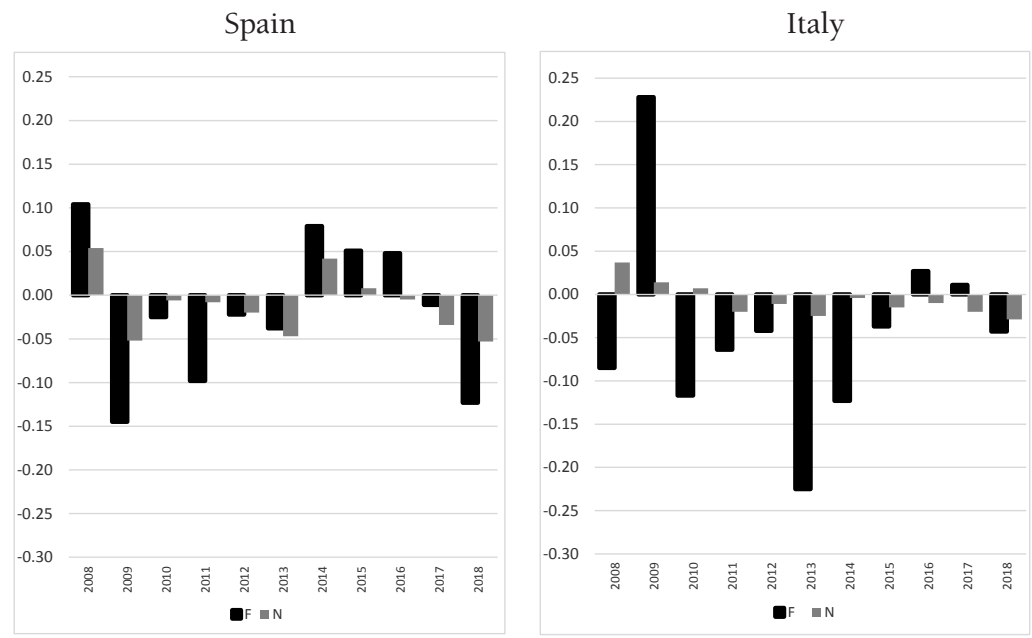

Greece

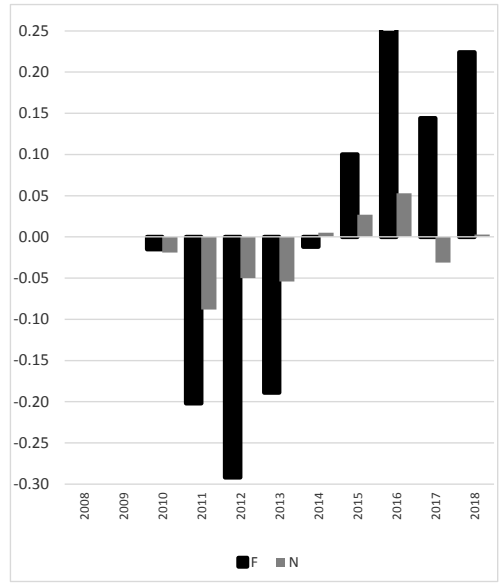

Source: EUROSTAT (2020), INE (2020), ISTAT (2020), ELSTAT (2020b \& c). Own elaboration

Figure 5. Spain, Italy, Greece, relative changes (\%) in overall TFR by citizenship (foreigners/nationals, 2009-2018)

Spain

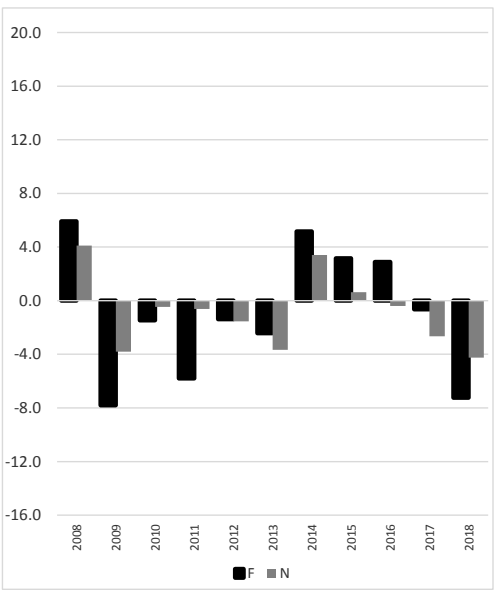

Italy

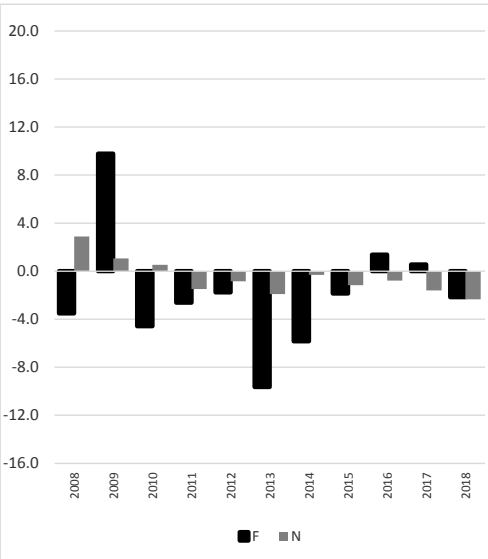

Greece

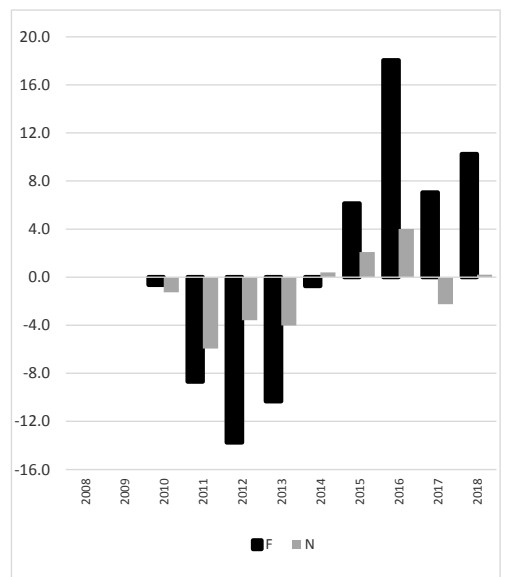

Source: EUROSTAT (2020), INE (2020), ISTAT (2020), ELSTAT (2020b \& c). Own elaboration

11 Simultaneously, the share of these women aged between 15-29 years in the female population of the same age quadrupled between 2015 and 2019 , rising from 7 to $28 \%$. 
Table 4. Spain, Italy, Greece, foreigners by origin

\begin{tabular}{|c|c|c|c|c|c|c|c|c|c|c|c|}
\hline & $\begin{array}{c}\text { Total } \\
\text { population* }\end{array}$ & $\begin{array}{l}\text { Foreigners } \\
\text { (all)* }\end{array}$ & $\begin{array}{l}(1) \\
\text { From } \\
\text { EU28* }\end{array}$ & $\begin{array}{c}\text { (2) From } \\
\text { all other } \\
\text { countries } / * *\end{array}$ & $\begin{array}{l}(2.1) \\
\text { From } \\
\text { EFTA* }\end{array}$ & $\begin{array}{l}\text { (2.2) From } \\
\text { Candidates } \\
\text { countries * }\end{array}$ & $\begin{array}{l}\text { (2.3) From } \\
\text { others } /^{* * *}\end{array}$ & 2.3 .1 & 2.3 .2 & 2.3 .3 & 2.3 .4 \\
\hline \multicolumn{12}{|l|}{ SPAIN } \\
\hline $01 / 01 / 2015$ & 46,450 & 4,454 & 1,948 & 2,505 & 0,032 & 0,009 & 2,464 & 0,829 & 0,147 & 0,230 & 1,258 \\
\hline$\%$ & 100.00 & 9.59 & 43.74 & 56.26 & 0.72 & 0.20 & 55.32 & 18.61 & 3.31 & 5.15 & 28.25 \\
\hline 01/01/2019 & 46,937 & 4,840 & 1,967 & 2,872 & 0,033 & 0,013 & 2,826 & 1,031 & 0,173 & 0,240 & 1,382 \\
\hline$\%$ & 100.00 & 10.31 & 40.63 & 59.34 & 0.67 & 0.28 & 58.39 & 21.31 & 3.57 & 4.96 & 28.55 \\
\hline \multicolumn{12}{|l|}{ ITALY } \\
\hline $01 / 01 / 2015$ & 60,796 & 5,014 & 1,492 & 3,522 & 0,010 & 0,634 & 2,878 & 0,901 & 0,043 & 0,511 & 1,423 \\
\hline$\%$ & 100.00 & 8.25 & 29.76 & 70.24 & 0.20 & 12.64 & 57.40 & 17.97 & 0.86 & 10.19 & 28.38 \\
\hline $01 / 01 / 2019$ & 60,360 & 5,255 & 1,583 & 3,672 & 0,010 & 0,564 & 3,097 & 0,909 & 0,046 & 0,686 & 1,456 \\
\hline$\%$ & 100.000 & 8.71 & 30.12 & 69.88 & 0.19 & 10.73 & 58.93 & 17.30 & 0.88 & 13.05 & 27.71 \\
\hline \multicolumn{12}{|l|}{ GREECE } \\
\hline $01 / 01 / 2015$ & 10,858 & 0,822 & 0,199 & 0,623 & 0,002 & 0,430 & 0,192 & 0,072 & 0,010 & 0,052 & 0,058 \\
\hline$\%$ & 100.000 & 7.57 & 24.21 & 75.79 & 0.24 & 52.31 & 23.36 & 8.76 & 1.22 & 6.33 & 7.06 \\
\hline $01 / 01 / 2019$ & 10,725 & 0,831 & 0,213 & 0,618 & 0,002 & 0,297 & 0,320 & 0,071 & 0,011 & 0,096 & 0,142 \\
\hline$\%$ & 100.000 & 7.75 & 25.63 & 74.37 & 0.24 & 35.74 & 38.51 & 8.54 & 1.32 & 11.55 & 17.09 \\
\hline \multicolumn{12}{|l|}{$\begin{array}{l}\text { W o m e } \mathrm{n} \\
15-49 \text { years }\end{array}$} \\
\hline \multicolumn{12}{|l|}{ SPAIN } \\
\hline $01 / 01 / 2015$ & 10,804 & 1.425 & 0,572 & 0,853 & 0,005 & 0,003 & 0,844 & 0,323 & 0,051 & 0,049 & 0,422 \\
\hline$\%$ & 100.00 & 13.19 & 40.15 & 59.84 & 0.37 & 0.22 & 59.25 & 22.65 & 3.59 & 3.40 & 29.61 \\
\hline $01 / 01 / 2019$ & 10,483 & 1,527 & 0,550 & 0,977 & 0,005 & 0,005 & 0,967 & 0,380 & 0,058 & 0,056 & 0.472 \\
\hline$\%$ & 100.00 & 14.56 & 36.00 & 63.98 & 0.33 & 0.31 & 63.32 & 24.90 & 3.80 & 3.69 & 30.93 \\
\hline \multicolumn{12}{|l|}{ ITALY } \\
\hline $01 / 01 / 2015$ & 13,366 & 1,666 & 0,589 & 1,076 & 0,002 & 0,183 & 0,892 & 0,326 & 0,016 & 0,117 & 0,433 \\
\hline$\%$ & 100.00 & 12.46 & 35.35 & 64.59 & 0.12 & 10.98 & 53.54 & 19.57 & 0.96 & 7.02 & 25.99 \\
\hline $01 / 01 / 2019$ & 12,548 & 1,599 & 0,564 & 1,034 & 0,002 & 0,161 & 0.872 & 0,303 & 0,016 & 0,133 & 0,420 \\
\hline$\%$ & 100.00 & 12.74 & 35.27 & 64.67 & 0.13 & 10.07 & 54.53 & 18.95 & 1.00 & 8.32 & 26.27 \\
\hline \multicolumn{12}{|l|}{ GREECE } \\
\hline $01 / 01 / 2015$ & 2,465 & 0.261 & 0.075 & 0,185 & 0,000 & 0.129 & 0,056 & 0,031 & 0,003 & 0,005 & 0,017 \\
\hline$\%$ & 100.00 & 10.59 & 28.74 & 70.88 & 0.00 & 49.43 & 21.46 & 11.88 & 1.15 & 1.92 & 6.51 \\
\hline $01 / 01 / 2019$ & 2,312 & 0.220 & 0.076 & 0,144 & 0,000 & 0.077 & 0,067 & 0,027 & 0,003 & 0,010 & 0,027 \\
\hline$\%$ & 100.00 & 9.52 & 34.55 & 65.45 & 0.00 & 35.00 & 30.45 & 12.27 & 1.36 & 4.55 & 12.27 \\
\hline
\end{tabular}

In Spain, both the total population and its distribution to nationals and foreigners is provided by INE

* Population in million

$* *$ From all other countries $(2)=(2.1+2.2+2.3)$

$* * *$ From others $(2.3)=(2.3 .1+2.3 .2+2.3 .3+2.3 .4)$

(2.3.1) Countries with high Human Development Index (HDI/HDC)

(2.3.2) Countries with very high Human Development Index (VHDI/VHDC)

(2.3.3) Countries with Low Human Development Index (LHDI/LDC)

(2.3.4) Countries with medium Human Development Index (MHDI/MDC)

Source: EUROSTAT (2020), INE (2020), ISTAT (2020), ELSTAT (2020b \& c). Own elaboration

\subsection{But different fertility patterns...}

The contribution of foreigners to overall TFR, as we have shown, is limited. Their higher TFR is mainly due to the higher age-specific fertility rates at younger ages and the examination of these rates (Figure 6) shows that, although those of nationals do not vary significantly between 2009 and 2018, the same does not apply to foreigners, especially in Greece and in Italy. Certainly, the differences between the two group rates are not only due to the calendar (tempo) but, mainly, to the differences in their period and cohort fertility. 

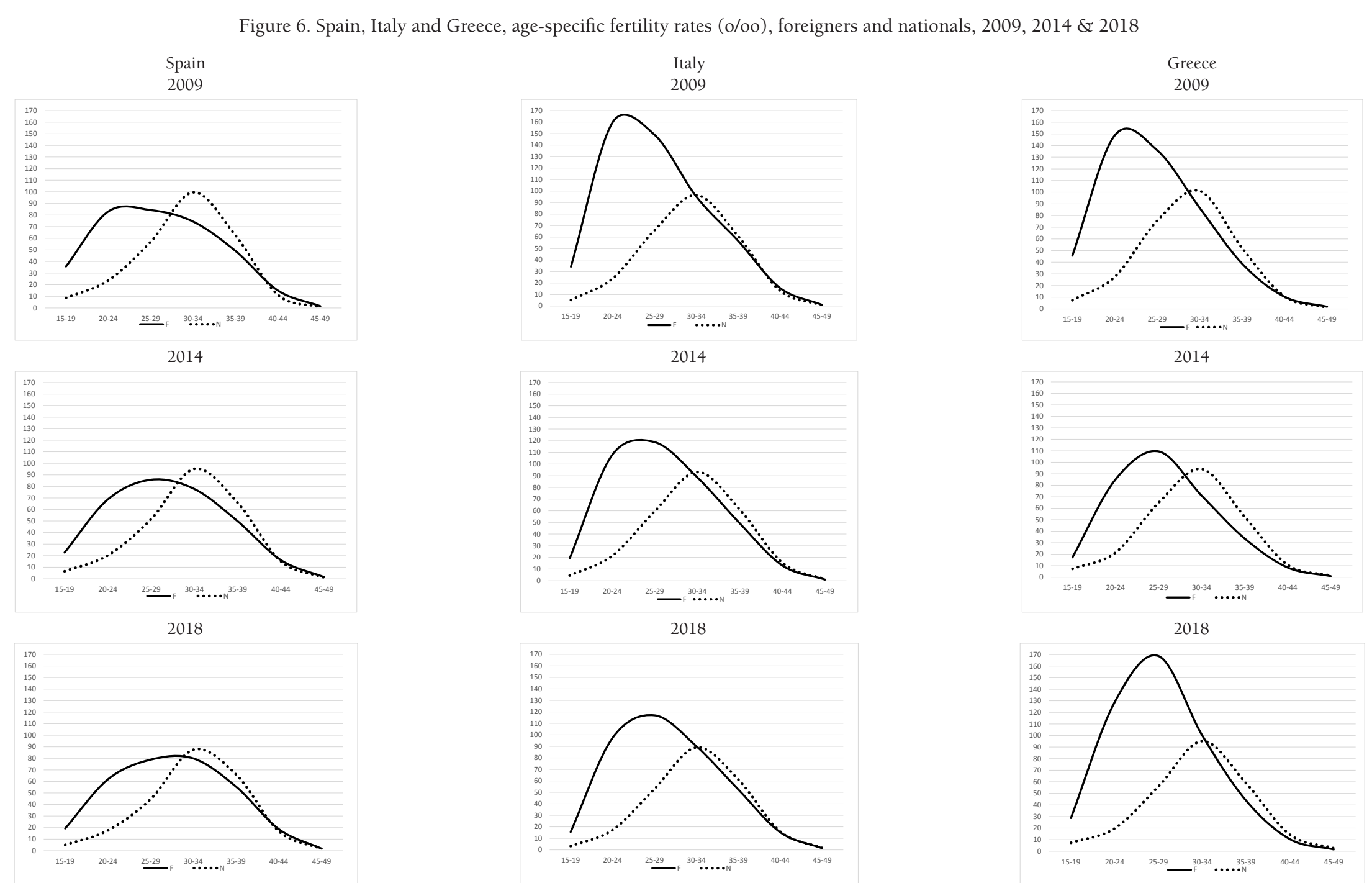

Source: EUROSTAT (2020), INE (2020), ISTAT (2020), ELSTAT (2020b \& c). Own elaboration 
We ought, therefore, to mention that i) the CFR of the successive generations in Spain, Italy, and Greece after 1940 declines continuously and this indicator for women born 1970-74 (estimation) is less than 1.6 children in Greece and 1.5 in Italy and Spain among the lowest in the EU countries (Breton, Barbieri, Belliot, d'Albis \& Mazuy, 2019); ii) in the developed countries (HDC and VHDC) were from the majority of foreigners settled in Spain, Italy, and Greece come from, the indirectly estimated completed fertility of the cohorts 1965-75 is less than 1.8 children/woman ${ }^{12}$, while in the MHDI ${ }^{13}$, is around 2.5 and in low HDI countries exceeds 3.5 children (UN, 2019a \& b).

\section{Discussion}

\subsection{Fertility between nationals and foreigners during the first years of recession}

The economic crisis in Spain and Italy emerged in 2008 and later in Greece. The recession led to a rapid decline of GDP in the following years, resulting in a significant reduction of household income, weakening consumer confidence, and increasing poverty as well unemployment. Although some papers referred - or focus - on the crisis impact on fertility in South European countries (Testa \& Stuart, 2012; Lanzieri, 2013; Cazzola, Pasquini \& Angeli, 2016; Caltabiano, Comolli \& Rosina, 2017; Fiori, Graham \& Rinesi, 2018; Kotzamanis, Kostaki \& Baltas, 2017; Kotzamanis, 2018; Comolli \& Vignoli, 2019; Tragaki \& Bagavos, 2019; Puig-Barrachina et al, 2019; Vignoli, Tocchioni \& Matei, 2019; Dantis \& Rizzi, 2020; Matysiak et al., 2020) rare examine its differential impact on the two components of the population (foreigners/nationals) and, when they deal with it, their analyses are based on data concerning mostly the period before 2015 (Paggiaro, 2013; Sobotka, 2017; Graham et al., 2016; Sabater \& Graham, 2019).

Figure 7 displays the changes during 2009-18 in the age-specific fertility rates for nationals and foreigners, and Table 5 the changes between 2009 and 2014. The results reveal firstly marked differences of different ages among the two groups at national level fertility trends. Thus, in Greece and Italy, (a) foreigners' fertility rates at all ages fell between 2009 and 2014, slightly more in the first country than in the second, (b) Italians and Greeks women rates have fallen only at ages below 35 and (c) between 15 and 35 years the rates decrease is faster for foreigners than for nationals, a fact that can be attributed to the greater vulnerability of the first group to unfavourable economic conditions.

Table 5. Spain, Italy, Greece, 2009-2014, variation (index numbers, 2009=100) of age specific fertility rates, foreigners and nationals

\begin{tabular}{|l|r|r|r|r|r|r|}
\cline { 2 - 7 } \multicolumn{1}{c|}{} & \multicolumn{2}{c|}{ SPAIN } & \multicolumn{2}{c|}{ ITALY } & \multicolumn{2}{c|}{ GREECE } \\
\cline { 2 - 7 } \multicolumn{1}{c|}{} & Nationals & \multicolumn{1}{c|}{ Foreigners } & Nationals & Foreigners & Nationals & Foreigners \\
\hline $15-19$ & 74.7 & 63.50 & 86.8 & 55.7 & 97.4 & 37.9 \\
\hline $20-24$ & 85.0 & 82.61 & 88.8 & 67.5 & 78.2 & 57.2 \\
\hline $25-29$ & 90.6 & 101.73 & 90.5 & 79.8 & 85.7 & 80.5 \\
\hline $30-34$ & 95.7 & 104.52 & 96.6 & 93.2 & 93.2 & 82.0 \\
\hline $35-39$ & 105.5 & 101.61 & 100.2 & 86.7 & 101.0 & 87.0 \\
\hline $40-44$ & 134.9 & 107.87 & 115.2 & 82.7 & 100.7 & 81.5 \\
\hline $45-49$ & 127.0 & 93.34 & 147.6 & 89.8 & 105.9 & 52.8 \\
\hline ICF & 97.0 & 93.94 & 96.1 & 77.7 & 91.6 & 69.7 \\
\hline
\end{tabular}

Source: EUROSTAT (2020), INE (2020), ISTAT (2020), ELSTAT (2020b \& c). Own elaboration

These difference trends conduct to the reduction of the TFRs gap and explain the decline in the overall TFR in those two countries the first years of the recession. On the contrary, in Spain, both among nationals and foreigners, the moderate rates drop concerns only 15-29 years. On the opposite, rates at mature ages (35-44 years) are not seem affected by the crisis, while those between 30 and 34 years behave deviant: in 2014, their values are lower than those of 2009 among Spanish and slightly higher among

\footnotetext{
12 Except in the majority of Central and South American countries as well as Iran and Tunisia where it exceeds slightly two children/ women.

13 China exempt.
} 
foreign women. Indeed, in this country, the recession seems to have a small influence, especially, rather surprisingly, among foreigners. However, a question must be asked about the quality of the data relating to the reference populations. An underestimation of these populations, stronger for foreigners than for Spanish at childbearing ages, if this is the case, gives higher fertility rates for both groups while reducing their differences.

Figure 7. Spain, Italy, Greece, 2009-2018, variation of age specific fertility rates, foreigners and nationals (base 100 in 2009)

Spain - Foreigners

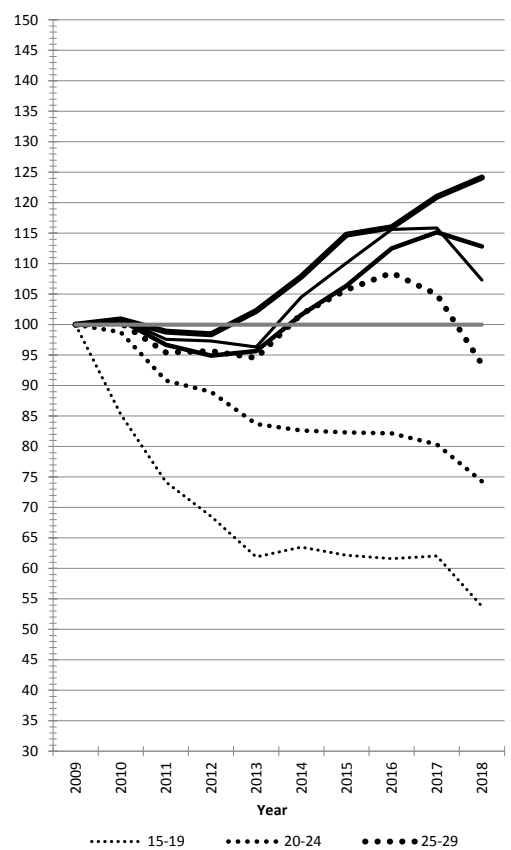

….....15-19 $\quad \cdots \cdot \ldots \cdot 20-24 \quad \cdots \cdots \cdot 25-29$

Spain - Nationals

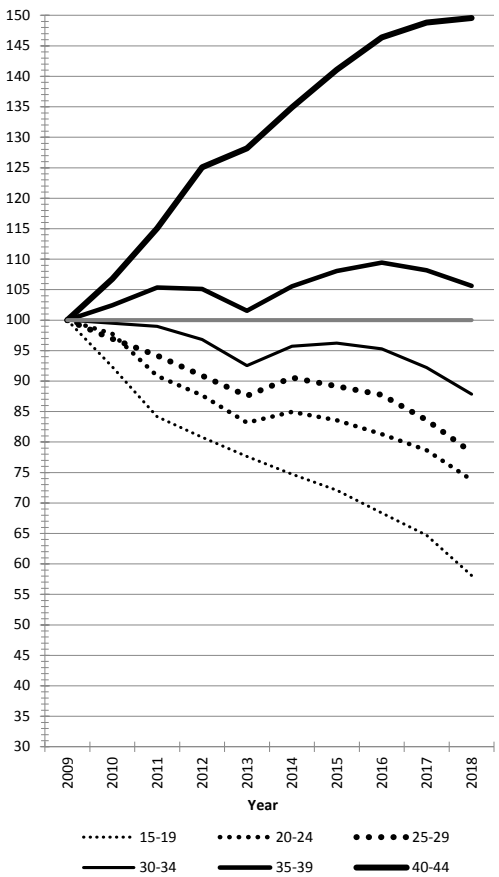

Italy - Foreigners

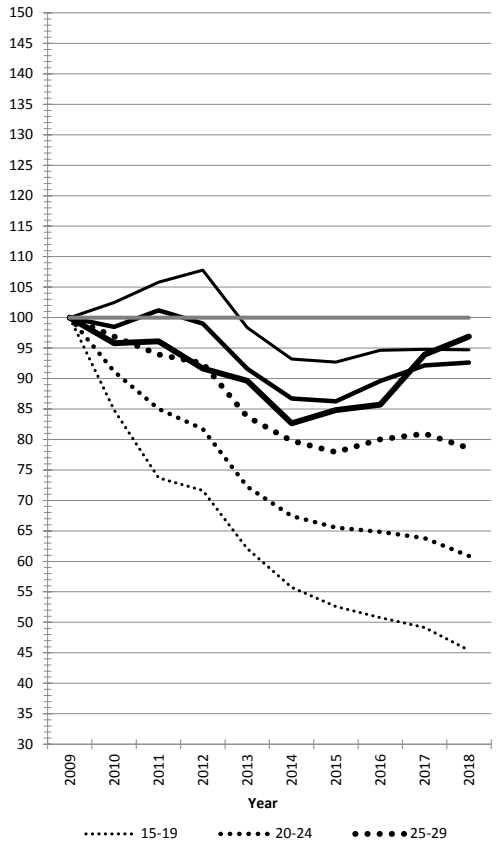

Italy - Nationals

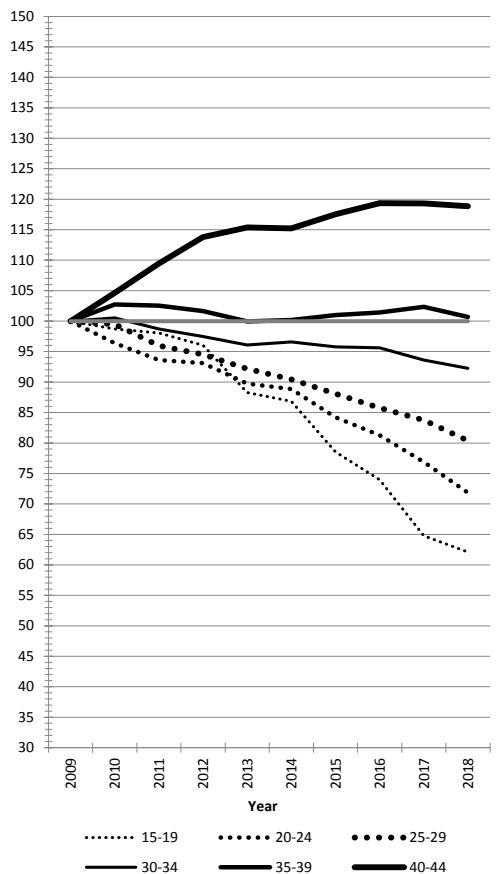

Greece - Foreigners

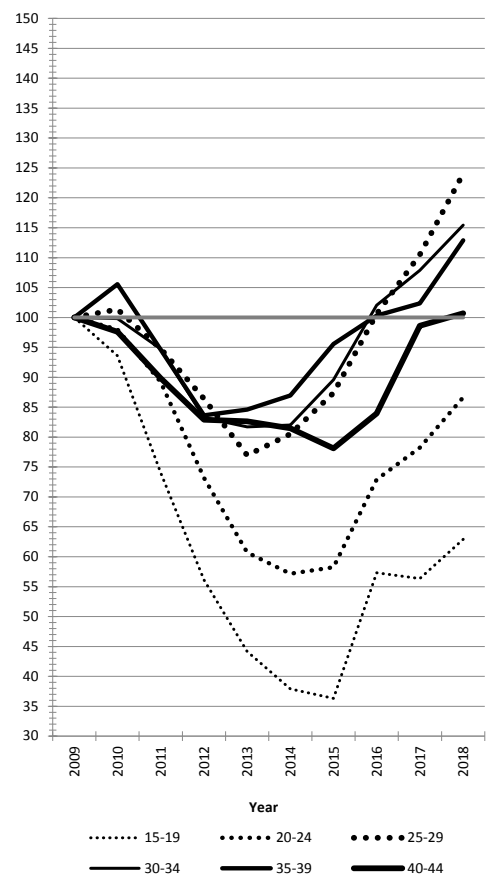

Greece - Nationals

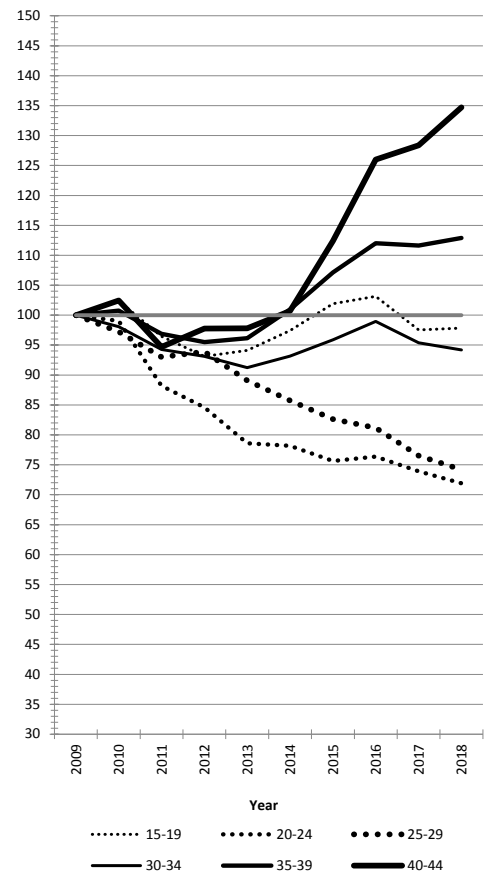

Source: EUROSTAT (2020), INE (2020), ISTAT (2020), ELSTAT (2020b \& c). Own elaboration 


\subsection{Differences in recent period fertility (before the Covid pandemic) between Greece, Spain and Italy (2014-2018)}

The evolution of national and foreign women's fertility indicators after 2014 differs significantly among the three Mediterranean countries (Table 6). If fertility recovers slightly in Spain and Italy, this moderate recovery, slightly more important for foreigners than for nationals, concerns only the mature ages, as the younger one continues to be, in 2018, for both groups, at lower levels than in 2014. Thus, the overall TFR in these countries is slightly lower in 2018 than in 2014, as the limited recovery at older ages did not allow its rise. In Greece, trends differ. The changes in rates between Greeks and foreign citizens are significantly different, and the TFR gap has been widening after 2014. A question, therefore, arises: what is the reason for these?

Table 6. Spain, Italy, Greece, 2014-2018, variation of age specific fertility rates, foreigners and nationals (base 100 in 2014)

\begin{tabular}{|l|r|r|r|r|r|r|}
\cline { 2 - 7 } \multicolumn{1}{c|}{} & \multicolumn{2}{c|}{ SPAIN } & \multicolumn{2}{c|}{ ITALY } & \multicolumn{2}{c|}{ GREECE } \\
\cline { 2 - 7 } \multicolumn{1}{c|}{} & Nationals & \multicolumn{1}{c|}{ Foreigners } & Nationals & \multicolumn{1}{c|}{ Foreigners } & Nationals & \multicolumn{1}{c|}{ Foreigners } \\
\hline $15-19$ & 77.8 & 84.68 & 71.5 & 81.5 & 100.4 & 165.9 \\
\hline $20-24$ & 86.8 & 89.90 & 80.9 & 90.2 & 92.0 & 151.6 \\
\hline $25-29$ & 86.5 & 91.90 & 88.9 & 98.5 & 86.5 & 154.1 \\
\hline $30-34$ & 91.8 & 102.69 & 95.5 & 101.6 & 101.1 & 140.8 \\
\hline $35-39$ & 100.1 & 111.03 & 100.5 & 106.8 & 111.8 & 129.8 \\
\hline $40-44$ & 110.9 & 115.05 & 103.2 & 117.2 & 133.8 & 123.6 \\
\hline $45-49$ & 148.9 & 122.01 & 143.5 & 134.8 & 195.9 & 159.2 \\
\hline ICF & 93.5 & 97.81 & 94.2 & 97.9 & 100.7 & 147.9 \\
\hline
\end{tabular}

Source: EUROSTAT (2020), INE (2020), ISTAT (2020), ELSTAT (2020b \& c). Own elaboration

To answer, we need to consider, among other facts, the changes that have taken place over the 2010 decade in both fertility and foreigners' profile in this country. It can be first suggested that as the foreigners' fertility has been affected severely by the recession, an important birth recovery thereafter is justified. We can also suggest that major changes in the composition of foreigners' population by nationality after 2014 , unlike in Italy and Spain, have reflected in their fertility.

The above hypotheses are supported by the comparative study on fertility rates by age. We can see that nationals' fertility rates under 30 years decreased slightly between 2014 and 2018, while an increase was only recorded at over 30s. In contrast, foreigner rates are rising rapidly at all ages. While this development for both nationals and foreigners aged over 30 years can be attributed mainly to a recovery of births, the significant increase recorded only among foreigners under 30 - an increase also affecting their average age at childbearing - can be reasonably attributed mainly to the increase of the percentages of women from MDC and LDC countries having much higher fertility than that of foreigners from VHDC and HDC countries. ${ }^{14}$

In summary, we can claim that, in Greece, during the last years, there is a coexistence of two discrete fertility models regarding foreigners. The first one concerns women of the first migration wave, coming, in the great majority, from Eastern Europe and the Balkans. Their fertility, slightly higher than that of the nationals, exhibits, even convergence trends like in countries with long migration tradition (Coleman, 1994; Schoorl, 1995; Alders, 2000; Østby, 2002; Andersson, 2004; Gebremariam \& Beaujot, 2010; Milewski, 2010; Dubuc, 2012; Persson \& Hoem, 2014; Camarota \& Zeigler, 2015; Rojas, Bernadi \& Schmid, 2018; Kulu et al., 2019). The second one is attributed to women from less developed countries who settled in Greece recently, having much higher fertility than the first migrant wave. In summary, we can claim that, in Greece, during the last years, there is a coexistence of two discrete fertility models regarding foreigners. The first one concerns women of the first migration wave, coming, in the great majority, from Eastern Europe and the Balkans. Their fertility, slightly higher than that of the nationals,

14 The fertility of the newcomers is also boosted by the "disruption fertility" a phenomenon widely referred to in the literature (Ford, 1990; Kulu, 2005; Persson \& Hoem, 2014), as these migrants were obliged to postpone their fertility for some time before their displacement, a fact also pinpointed by Castro-Martín \& Rosero Bixby (2011) concerning those foreign women coming to Spain from Africa. 
exhibits, even convergence trends like in countries with long migration tradition. The second one is attributed to women from less developed countries who settled in Greece recently, having much higher fertility rate than the first migrant wave.

Finally, regardless of the "Greek" peculiarity, we must point out that, although in all three countries foreigners' fertility has a limited impact on overall TFR, this group has contributed - and will keep contributing - at relatively high rates $(>10 \%)$ - to births, and, in this way, reducing their negative natural balance (Figure 8 ). Thus, if foreigners have not reversed these balances' negative signs, they significantly reduced the losses.

Figure 8. Spain, Italy, Greece, natural balance, foreigners and nationals, 2009-2018
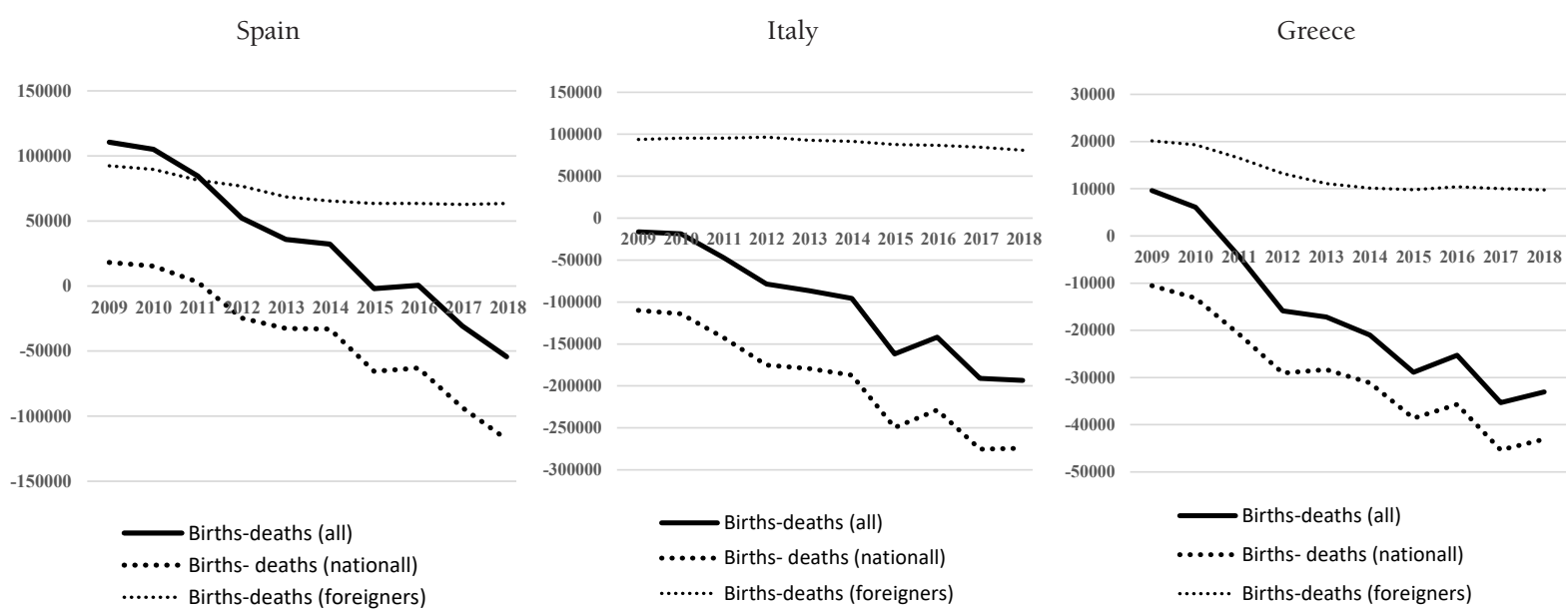

Source: EUROSTAT (2020), INE (2020), ISTAT (2020), ELSTAT (2020b \& c). Own elaboration

\section{Conclusions}

The present study examines period fertility levels and trends between foreigners and nationals in Spain, Italy, and Greece for 2009-2018. The analysis results indicate that (i) fertility rates in the three South-European countries hold the lowest ranks in Europe because nationals' fertility is extremely low. (ii) Although foreigners make a major contribution to births, their net effect on overall TFR is moderate. (iii) Foreign women's fertility fluctuated over a wider range than that of the nationals. iv) The fertility of those settled in the 1990s and 2000s in Greece and - to a lesser extent - in Italy has proven more vulnerable to the recent economic downturn as their rates declined faster in the first years of the 2010 decade. v) Foreigners' TFR, after 2014, increased significantly in Greece, but not in Spain and Italy. This increase is due not only to the recovery of delayed births during the first years of the recession, but also to the composition changes on foreign population by nationality, i.e., to the increase of weight of women from MDC and LDC countries characterized by much high fertility. vi) Foreigners will keep contributing, at relatively high rates $(>10 \%)$, to births in Spain, Italy and Greece and, in this way, to the reduction of their negative natural balance.

Comparing Spain, Italy and Greece with other European countries enables us to include them in one of the four existing distinct groups (OECD, 2015; Volant, Pison \& Héran, 2019). The first comprises countries where the \% of foreigners are too small to influence fertility rates (mainly the former communist countries of Central or Eastern Europe). The second includes countries (such as France, Belgium, Luxembourg and Austria) having both a relatively important part of foreign origin female population and a relatively large difference between nationals and foreigners' fertility. The third group, countries that even if they have a significant percentage of foreign women, their fertility impacts are quite limited. The last group comprises a relatively small number of countries (Iceland, Denmark and - to a lesser extent - Sweden, Norway and Finland). Immigrant/foreign women in this group have similar to - or even lower fertility rates than nationals. Based on our analyses, the three South-European countries belong rather to the third group, as the presence of foreign/immigrant women has - and probably will continue to have - a positive but quite limited net effect on their TFRs. 


\section{Funding}

This article's writing was supported by the Hellenic Foundation for Research and Innovation (Research Project 'Demographic Imperatives in Research and Practices in Greece').

\section{Acknowledgments}

The author acknowledges the Hellenic Statistical Authority for providing the data as well as Julián López Colás (Researcher at the Universitat Autònoma de Barcelona), Francisco Zamora López (Professor of Demography, Department of Applied Sociology Universidad Complutense de Madrid) and Miriam Carella, (Professore Aggregato di Statistica sociale e Demografia, Dipartimento di Scienze Politiche, Università di Bari "Aldo Moro") for their help.

\section{References}

Adserà, A., \& Ferrer, A. (2015). Immigrants and demography: Marriage, divorce, and fertility. In Chiswick, B.R., \& Miller, P.W. (Eds.). Handbook of the economics of international migration (pp. 315-374). Oxford and Amsterdam: Elsevier. https://doi.org/10.1016/B978-0-44453764-5.00007-4

Alderotti, G., Mussino, E., \& Comolli, C. (2019). Natives and migrants' childbearing during the great recession: A comparison between Italy and Sweden. Stockholm Research Reports in Demography, 17. Retrieved from https://su.figshare.com/articles/Natives_and_Migrants_Childbearing during the Great_Recession_A_Comparison_between_Italy_and_Sweden/8175446/1

Alders, M. (2000). Cohort fertility of migrant women in the Netherlands. In Paper presented at the BSPSNVD-URU Conference in Utrecht (the Netherlands).

Andersson, G. (2004). Childbearing after migration: fertility patterns of foreign-born women in Sweden, International Migration Review, 38(2), 747-774. https://doi.org/10.1111/j.1747-7379.2004.tb00216.x

Arango, J. (2000). Becoming a country of immigration at the end of the twentieth century: The case of Spain. In R. King, G. Lazaridis, \& C. Tsardanidis (Eds.), Eldoradoor Fortress? Migration in Southern Europe (pp. 253-276). London: Macmillan. https://doi.org/10.1057/9780333982525_12

Arslan, C., Dumont, J.C., Kone, Z., Moullan, Z., Ozden, Z., Parsons, C., \& Xenogiani, T. (2014). A new profile of migrants in the aftermath of the recent economic crisis. Paris: Organisation for Economic Cooperation and Development (OECD Social, Employment and Migration Working Papers 160). https://doi.org/10.1787/1815199X

Arslan, C., Dumont, J.C., Kone, Z., Moullan, Z., Ozden, Z., Parsons, C., \& Xenogiani, T. (2016). International Migration to the OECD in the 21st Century.

Ayllon, S. (2019). Job insecurity and fertility in Europe. Review of Economics of the Household, 17, 13211347. https://doi.org/10.1007/s11150-019-09450-5

Bagavos C., Tsimbos, C., \& Verropoulou, G. (2008). Native and migrant fertility patterns in Greece: A cohort approach. European Journal of Population, 24(3), 245-263.

Bagavos, C. (2019). On the multifaceted impact of migration on the fertility of receiving countries: Methodological insights and contemporary evidence for Europe, the United States, and Australia, Demographic Research, 41(1), 1-36.

Bagavos, C., Verropoulou, G., \& Tsimbos, C. (2018). Assessing the contribution of foreign women to period fertility in Greece, 2004-2012. Population, 73(1), 119-130. https://doi.org/10.3917/popu.1801.0119

Barbieri, P., Bozzon, R., Scherer, S., Grotti, R., \& Lugo, M. (2015). The rise of a Latin model? Family and fertility consequences of employment instability in Italy and Spain. European societies, 17(4), 423-446. https://doi.org/10.1080/14616696.2015.1064147

Bayona-i-Carrasco, J., Thiers Quintana, J., \& Avila-Tàpies, R. (2017). Economic recession and the reverse of internal migration flows of Latin American immigrants in Spain. Journal of Ethnic and Migration Studies, 43(15), 2499-2518. https://doi.org/10.1080/1369183X.2017.1296354

Bellido, H., \& Marcen, M. (2016). Fertility and the Business Cycle: The European Case. Munich. 
Bermudez, A., \& Brey, E. (2017). Is Spain becoming a Country of Emigration Again?. In J.M. Lafleur \& M. Stanek (Eds.), South-North Migration of EU Citizens in Times of Crisis (pp. 83-98). IMISCOE Research Series. Springer, Cham.

Bonifazi, C. (2013). LItalia delle migrazioni. Bologna : Il Mulino.

Bonifazi, C., \& Strozza, S. (2017). Le migrazioni internazionali nei paesi meridionali dell'Unione Europea prima e dopo la crisi. In E. Ferragina (Ed.), Rapporto sulle economie del Mediterraneo (pp. 161- 184). Bologna: il Mulino.

Breton, D., Barbieri, M., Belliot,B., d'Albis, H., \& Mazuy, M. (2019). L'évolution démographique récente de la France: une singularité en Europe?. Population, 74(4), 409-497. https://doi.org/10.3917/ popu.1904.0409

Bueno, X., \& Devolder, D. (2012). Age at Migration and Fertility Patterns in Spain: Differences by Origin and Length of Stay. Centre d'Estudis Demogràfics: Barcelona.

Burkimsher, M., Rossier, C., \& Wanner, P. (2018). Who has more children in Switzerland? Swiss or foreign women? Why the TFR is a misleading measure. LIVES Working Paper 73.

Caltabiano, M., Comolli, C.L., \& Rosina, A. (2017). The effect of the Great Recession on permanent childlessness in Italy. Demographic Research, 37, 635-668. https://doi.org/10.4054/DemRes.2017.37.20

Camarota, S., \& Zeigler, K. (2015). The declining fertility of immigrants and natives. Washington, D.C.: Center for Immigration Studies. Retrieved from http://cis.org/sites/cis.org/files/camarotadecliningfertility.pdf

Castro-Martín, T., \& Rosero-Bixby, L. (2011). Motherhood and transnational borders: Immigrants' women fertility in Spain. Revista Internacional de Sociologia, 69, 105-137.

Cazzola, A., Pasquini, L., \& Angeli, L. (2016). The relationship between unemployment and fertility in Italy. Demographic Research, 34(1), 1-38. https://doi.org/10.4054/DemRes.2016.34.1

Cerrutti, M., \& Maguid, A. (2016). Crisis económica en España y el retorno de inmigrantes sudamericanos. Migraciones Internacionales, 8(3), 155-189.

Coleman, D. (1994). Trends in fertility and intermarriage among immigrant populations in Western Europe as measures of integration. Journal of Biosocial Science, 26, 107-136. https://doi.org/10.1017/ $\underline{\text { S0021932000021106 }}$

Colombo, A., \& Dalla Zuanna, G. P. (2019). Immigration Italian Style, 1977-2018. Population and Development Review, 45(3), 585-615. https://doi.org/10.1111/padr.12275

Comolli, C. L. (2017). The fertility response to the Great Recession in Europe and the United States: Structural economic conditions and perceived economic uncertainty. Demographic Research, 36, 1549-1600. https://doi.org/10.4054/DemRes.2017.36.51

Comolli, Ch. L., \& Vignoli, D. (2019). Spread-ing uncertainty, shrinking birth rates. Econometrics Working Papers Archive 2019_08, Universita' degli Studi di Firenze, Dipartimento di Statistica, Informatica, Applicazioni "G. Parenti”. Retrieved from https://local.disia.unifi.it/wp_disia/2019/wp_disia_2019_08. pdf

Cornelius, W. A. (2004). Spain: the uneasy transition from labor exporter to labor importer. In W.A. Cornelius, P. L. Martin, \& J.F. Hollifield (Eds.), Controlling immigration: aglobal perspective, $2^{\text {nd }}$ edition (pp. 387-429). Standford, C.A.: Stanford University Press.

Dantis, Ch., \& Rizzi, E.L. (2020). Transition to first birth during the Great Recession: the case of Greece. Genus, 76. https://doi.org/10.1186/s41118-019-0070-1

De Bartolo, G., \& Stranges, M. (2008). Stime della fecondità delle straniere in Italia per nazionalità attraverso l'applicazione di funzioni matematiche. Rivista Italiana di Economia Demografia e Statistica, LXII, 351-357.

Del Rey, A., \& Grande, R. (2015). A Longitudinal Analysis on Reproduction Behavior. In A. Domingo, A. Sabater, and R. Verdugo (Eds.), Demographic analysis of Latin American immigrants in Spain: From boom to bust (pp. 133-154). New York: Springer.

Del Rey, A., \& Parrado, E. (2012). The Fertility of Immigrant Women: Family Dynamics, Migration, and Timing of Childbearing. Paper supported by the project CSO2010-16413 from the Spanish Ministry of Science and Innovation and by the Ramon y Cajal Fellowship. Retrieved from https://epc2012. princeton.edu/papers/120243 
Delgado, M., \& Zamora López, F. (2003). Españolas y extranjeras: su aportación a la fecundidad en España. Economistas, 99, 88-97.

Delgado, M., \& Zamora López, F. (2006). La contribución de las mujeres extranjeras a la dinámica demográfica en España. Sistema, (190-191), 143-166.

Devolder, D. (2006). La natalidad y la fecundidad de extranjeros en Cataluna. Barcelona: Centre d'Estudis Demogràfics, Papers de Demografía, 291. Retrieved from https://core.ac.uk/download/pdf/288483604.pdf

Devolder, D., \& Bueno, X. (2011). Effects of migration on fertility patterns of non native women in Spain. Barcelona: Centre d'Estudis Demogràfics, Papers de Demografía, 382. Retrieved from https://ddd.uab. cat/pub/worpap/2011/221050/papersdemografia_a2011n382.pdf

Devolder, D., \& Treviño, R. (2007). Efectos de la inmigración extranjera sobre la evolución de la natalidad de la fecundidad en España. Barcelona: Centre d'Estudis Demogràfics, Papers de Demografía, 321.

Domingo, A., \& Ortega-Rivera, E. (2015). Acquisition of nationality as Migration Policy. In A. Domingo, A. Sabater, and R. Verdugo (Eds.), Demographic analysis of Latin American immigrants in Spain: From boom to bust (pp. 29-54). New York: Springer. https://doi.org/10.1007/978-3319-12361-5_2

Dubuc, S. (2012). Immigration to the UK from high-fertility countries: Intergenerational adaptation and fertility convergence. Population and Development Review, 38(2), 353-368. https://doi.org/10.1111/ j.1728-4457.2012.00496.x

ELSTAT (2020a). 2011 Population and Housing Censuses. Retrieved from https://www.statistics.gr/en/ statistics/pop

ELSTAT (2020b). Estimated population of Greece. Retrieved from https://www.statistics.gr/en/statistics/-/ publication/SPO18

Escribano, A. I. (2006). Demografía de los extranjeros, incidencia en el crecimiento de la población. Bilbao: Fundación BBVA.

European Commission (2016-2019). European Economy forecast. Luxembourg: Publications Office of the European Union.

EUROSTAT (2020). Population and social conditions. Retrieved from https://ec.europa.eu/eurostat/data/ database, (demography and migration).

Ferrara, R., Giorgi P., Mamolo, M., \& Stroza, S. (2009). Fertility in Italy and Spain: What is the roleplayed by foreigners? A decomposition model results. Paper presented at the XXVI IUSSP International Population Conference. Marrakech, Morocco, 27 September - 2 October 2009.

Fiori, F., Graham, E., \& Rinesi, F. (2018). Economic reasons for not wanting a second child: Changes before and after the onset of the economic recession in Italy. Demographic Research, 38, 843-854. https://doi.org/10.4054/DemRes.2018.38.30

Ford, K. (1990). Duration of residence in the United States and the fertility of U.S. immigrants. International Migration Review, 24(1), 34-68.

Gabrielli, G., Paterno, A., \& Strozza, S. (2007). Dynamics, Characteristics and Demographic Behaviour of Immigrants in Some South-European Countries. In Characteristics and Demographic Behaviour of Immigrants in Different South-European Contexts. Lomonosov University, Moscow, Volume: Migration and Development. Retrieved from https://www.researchgate.net/profile/Gabrielli-Giuseppe/ publication/259867250_Dynamics_Characteristics_and_Demographic_Behaviour_of_Immigrants in_Some_South-European_Countries/links/Odeec52e3b7a6239f8000000/Dynamics-Characteristicsand-Demographic-Behaviour-of-Immigrants-in-Some-South-European-Countries.pdf

Gebremariam, W., \& Beaujot, R. (2010). Fertility behavior of immigrants in Canada: Converging trends. London: Populations Studies Centre, University of Western Ontario (PSC Discussion Papers Series 10-05). Retrieved from https://ir.lib.uwo.ca/cgi/viewcontent.cgi?article=1138\&context=pscpapers

Giannantoni, P., Mussino, E., Gabrielli, G., \& Strozza, S. (2016). How many and when? Different approaches to study fertility of migrants in Italy. Retrieved from https://epc2016.princeton.edu/ papers/161007

Giannantoni, P., Ortensi, L. E., Strozza, S., \& Gabrielli, G. (2019). La fecondita degli stranieri: misure e determinants. In ISTAT (Ed.), Vita e percorsi di integrazione degli immigrati in Italia (pp. 101-121). Rome: ISTAT. 
Giannantoni, P., \& Strozza, S. (2015). Foreigners' contribution to the evolution of fertility in Italy: A re-examination of the decade 2001-2011. Rivista Italiana di Economia Demografia e Statistica, 69(2), $129-140$.

Goldstein, J. R., Kreyenfeld, M., Jasilioniene, A., \& Orsal, D. D. K. (2013). Fertility reactions to the 'Great Recession' in Europe. Demographic Research, 29(4), 85-104. https://doi.org/10.4054/ DemRes.2013.29.4

González-Ferrer, A., Castro-Martín, T., \& Kraus, E. (2015). Childbearing among women of immigrant and non-immigrant origin in Spain. Country-specific case studies on fertility among the descendants of immigrants. Families \& Societies. Working Paper Series, 39. Retrieved from http://www. familiesandsocieties.eu

González-Ferrer, A., Castro-Martín, T., Kraus, E.K., \& Eremenko, T. (2017). Childbearing patterns among immigrant women and their daughters in Spain: Over-adaptation or structural constraints? Demographic Research, 37(1), 599-634. https://doi.org/10.4054/DemRes.2017.37.19

González-Ferrer, A., \& Trilla, C. (2011). Naturalisation decisions in Spain. The importance of legal assymetrics. Communication at PAA 2011 Conference. Retrieved from https://paa2011.princeton.edu/ papers/112356

Graham, E., Sabater, A., \& Fiori, F. (2016). Fertility change in the context of economic recession in Italy and Spain. ESRC Centre for Population Change, Briefing 36. Retrieved from https://eprints.soton. ac.uk/399527/1/Briefing_36_Fertility_Change_in_the_Context_of_Economic_Recession.pdf

Guerrizio, M. A., Sonnino, E., \& Strozza, S. (2003). La fecondità degli stranieri in Italia: tra indizi e valutazionipresuntive. In E. Sonnino (Ed.), La popolazione straniera in Italia (1986-1996): matrimoni, nascite, stimedi fecondità (pp. 107-140). Rome: Collana del Dipartimento di Scienze Demografiche, Sapienza University of Rome.

Hierro-Hernández, M.J., \& Torre-Fernández, M. (2010). ¿Querer es poder? Un análisis de la fecundidad de las mujeres españolas e inmigrantes. Madrid: Fundación Alternativas (Estudios de Progreso 49).

Impicciatore, R., Gabrielli, G., \& Paterno A. (2020). Migrants' fertility in Italy: A comparison between origin and destination. European Journal of Population 1-27.

INE (2020). INEbase (Demography and population). Retrieved from https://www.ine.es/dyngs/INEbase/ es/operacion.htm?c=Estadistica_C\&cid=1254736176951\&menu=ultiDatos\&idp=1254735572981)

ISTAT (2020). Population and households. Retrieved from https://www.istat.it/en

King, R., \& Okólski, M. (2019). Diverse, fragile and fragmented: The new map of European migration. Central and Eastern European Migration Review, 8(1), 9-32.

Kotzamanis, B. (2018). La crise actuelle en Grèce et ses conséquences sur la population. In V. Golaz, C. Lefevre, \& J. Veron (Eds.), La crise dix ans après. Quels effets sur la conjoncture démographique des pays d'Europe du Sud ?, Documents de travail, 239 (pp. 21-45). Paris : Ined.

Kotzamanis, B., Carella, M., Duquenne, M.N., \& Pappas, V. (2020). Asylum seekers into southern European countries (Greece, Italy, Spain) over the last decade: a first comparative approach. In J.D. Sempere Souvannavong, C. Cortés Samper, E. Cutillas Orgilés \& J.R. Valero Escandell (Eds.), Población y territorio. España tras la crisis (pp. 299-312). Granada: Comares.

Kotzamanis, B., \& Karkanis, D. (2018). International migrations in Greece during the last decades: inversion of tendencies and refugees waves. In B. Kotzamanis \& A. Parant (Eds.), Regards sur la population de l'Europe du Sud-est/ Viewpoints on Population in South-East Europe (pp. 299-309). Athens : Demobalk,

Kotzamanis, B., \& Karkanis D. (2019). Foreigners can give a solution to the low fertility of Greece's population. Demographic News, 36 (in Greek). Retrieved from http://www.e-demography.gr/news/ docs/eDemography_News_Doc_00016_gr.pdf

Kotzamanis, B., Kostaki, A., \& Baltas, B. (2017). The evolution of Period fertility in Greece and Its changes During the Current Economic Recession. Population Review, 56(2), 127-145

Kotzamanis, B., \& Sofianopoulou, K. (2008). The contribution of foreigners to the fertility of the population of Greece (in Greek). DemoNews, 1. Retrieved from http://www.demography-lab.prd.uth. gr/DemoNews/1-SepOkt08.pdf 
Kraus, E., \& Castro-Martín, T. (2017). Does Migrant Background Matter for Adolescents' Fertility Preferences? The Latin American 1.5 Generation in Spain. Eur J Population.

Kreyenfeld, M., Anderson, G., \& Pailhe, A. (2012). Economic uncertainty and family dynamics in Europe; Introduction. Demographic Research, 27(28), 835-852. https://doi.org/10.4054/DemRes.2012.27.28

Kulu, H. (2005). Migration and fertility: Competing hypotheses re-examined. European Journal of Population, 21(1), 51-87. https://doi.org/10.1007/s10680-005-3581-8

Kulu, H., \& González-Ferrer, A. (2014). Family Dynamics Among Immigrants and Their Descendants in Europe: Current Research and Opportunities. Eur J Population, 30, 411-435. https://doi.org/10.1007/ $\underline{\text { s10680-014-9322-0 }}$

Kulu, H., Hannemann, T., Pailhé, A., Neels, K., Rahnu, L., Puur, A., \& Persson, L. (2015). A comparative study on fertility among the descendants of immigrants in Europe. Families and Societies, Working paper Series, 40, 1-34.

Kulu, H., Milewski, N., Hannemann, T., \& Mikolai, J. (2019). A decade of lifecourse research on fertility of immigrants and their descendants in Europe. Demographic Research, 40(46), 1345-1374. https:// doi.org/10.4054/DemRes.2019.40.46

Labrianidis,L., \& Pratsinakis, M. (2016). Greece's new emigration at time of Crisis. European Insitute, Hellenic Observatory Papers on Greece and Southeast Europe, 99. Retrieved from https://www.lse. ac.uk/Hellenic-Observatory/Assets/Documents/Publications/GreeSE-Papers/GreeSE-No99.pdf

Lanzieri, G. (2013). Towards a 'baby recession' in Europe? Differential fertility trends during the economic crisis, Statistics in Focus, 13. Retrieved from http://gesd.free.fr/kssf1313.pdf

Larramona, G. (2013). Out-migration of immigrants in Spain. Population, 222(68), 249-271. https://doi. org/10.3917/popu.1302.0249

Mamolo, M., \& Ferrara, R. (2009). Il contributo delle donne immigrate alla fecondità in Italia e in Spagna. Neodemos.Florence. Retrieved from http://www.neodemos.info/articoli/ilcontributo-delle-donneimmigrate-alla-fecondit-in-italia-e-in-spagna/

Matysiak, A., Vignoli, D., \& Sobotlka, T. (2020). The Great recession and fertility in Europe: a Subnational Analysis. European Journal of Population. https://doi.org/10.1007/s10680-020-09556-y

Milewski, N. (2010). Fertility of immigrants. A two-generational approach in Germany. Hamburg: Springer Demographic Research Monographs. https://doi.org/10.1007/978-3-642-03705-4

Mussino, E., \& Cantali, S. (2020). Multiple-origin and Multiple-destination: the fertility of migrants in Europe. Stockholm Research Reports in Demography, 47.

Mussino, E., Gabrielli, G., Ortensi, L.E., \& Strozza, S. (2020). Fertility Intentions Within a 3-Year Time Frame: a Comparison Between Migrant and Native Italian women. Journal of International Migration and Integration. https://doi.org/10.1007/s12134-020-00800-2

Mussino, E., Gabrielli, G., Paterno, A., Strozza, S., \& Terzera, L. (2012). Il comportamento riproduttivo e le strategie migratorie degli stranieri presenti in Lombardia. Rivista Italiana di Economia, Demografia e Statistica, LXVI(1), 197-204.

Mussino, E., Gabrielli, G., Paterno, A., Strozza, S., \& Terzera, L. (2015). Motherhood of foreign women in Lombardy: Testing the effects of migration by citizenship. Demographic Research, 33(23), 653-664. https://doi.org/10.4054/DemRes.2015.33.23

Mussino, E., Iaccarino, C., Prati, S., \& Strozza, S. (2009). Short-term reproductive behaviour of foreign women who became mothers between 2002-2006 in Italy. In Vienna Yearbook of Population Research (pp. 63-82).

Mussino, E., \& Strozza, S. (2012a). The fertility of immigrants after arrival: The Italian case. Demographic Research, 26(4), 97-130. https://doi.org/10.4054/DemRes.2012.26.4

Mussino, E. \& Strozza, S. (2012b). Does citizenship still matter? Second birth risks of resident foreigners in Italy. European Journal of Population, 28(3), 269-302. https://doi.org/10.1007/s10680-012-9261-6

Mussino, E., \& Van Raalte, E. (2013). Immigrant fertility: A comparative study between Italy and Russia. International Migration, 51(2), 148-164. https://doi.org/10.1111/j.1468-2435.2012.00760.x 
Natale, M., \& Strozza, S. (1997). Gli immigrati stranieri in Italia. Quanti sono, chi sono, come vivono?. Bari: Cacucci Editore.

OECD (2014). Society at a Glance 2014: OECD Social Indicators. Paris: OECD Publishing. http://dx.doi. org/10.1787/soc_glance-2014-en

OECD. (2015). Indicators of Immigrant Integration 2015: Settling In. Paris: OECD Publishing. http://dx.doi. org/10.1787/9789264234024-en

OECD (2019). International Migration Outlook 2019. Paris: OECD Publishing. https://doi.org/10.1787/ c3e35eec-en

Ortensi L.E. (2012). La fecondità delle straniere. In G.C. Blangiardo (Ed.), Limmigrazione straniera in Lombardia L'undicesima indagine regionale. Milano: Osservatorio Regionale per l'integrazione e la Multietnicità, Retrieved from https://www.researchgate.net/publication/236109100_La_fecondita_ delle_straniere

Ortensi, L.E. (2015). Engendering the fertility/migration nexus: The role of women's migratory patterns in the analysis of fertility after migration. Demographic Research, 32(53), 1435-1468. https://doi. org/10.4054/DemRes.2015.32.53

Østby, L. (2002). The demographic characteristics of immigrant populations in Norway. Reports, 2002/22, Oslo: Statistics Norway.

Paggiaro, A. (2013). How do immigrants fare during the downturn? Evidence from matching comparable natives. Demographic Research, 28(8), 229-258. https://doi.org/10.4054/DemRes.2013.28.8

Persson, L., \& Hoem, M. J (2014). Immigrant fertility in Sweden, 2000-2011: A descriptive note. Demographic Research, 30(30), 887-898. https://doi.org/10.4054/DemRes.2014.30.30

Pissarides, Chr., Vafianos, D., Vettas, N., \& Megir, K. (2020). Growth plan for Greek economy, intermediate report (in Greek). Retrieved from https://government.gov.gr/schedio-anaptixis-gia-tinellinikiikonomia-endiamesi-ekthesi

Prieto-Rosas, V., \& Quintero-Lesmes, D.C. (2018). Migration responses of immigrants in Spain during the Great Recession. Demographic Research, 38(61), 1885-1932. https://doi.org/10.4054/ DemRes.2018.38.61

Puig-Barrachina, V., Rodríguez-Sanz, M., Domínguez-Berjón, M.F., Martín, U., Luque, M. Á., Ruiz, M., \& Perez, G. (2019). Decline in fertility induced by economic recession in Spain. Gaceta Sanitaria, 34(3), 238-244. https://doi.org/10.1016/j.gaceta.2019.05.011

Recaño, J., Roig, M., \& de Miguel, V. (2015). Spain: A new gravity centre for Latin American migration. In A. Domingo, A. Sabater, and R. Verdugo (Eds.), Demographic analysis of Latin American immigrants in Spain: From boom to bust (pp. 181-209). New York: Springer.

Roig Vila, M., \& Castro-Martín, T. (2007a). Immigrant Mothers, Spanish Babies: Childbearing Patterns of Foreign Women in Spain. Documentos de trabajo, 17, 5-38.

Roig Vila M., \& Castro-Martín, T. (2007b). Childbearing patterns of foreign women in a new immigration country: The case of Spain. Population-E, 62(3), 351-380. https://doi.org/10.3917/pope.703.0351

Rojas, E.A.G., Bernardi, L., \& Schmid, F. (2018). First and second births among immigrants and their descendants in Switzerland. Demographic Research, 38, 247-286. https://doi.org/10.4054/ DemRes.2018.38.11

Sabater, A., \& Graham, E. (2019). International Migration and Fertility Variation in Spain during the Economic Recession: A Spatial Durbin Approach, Apl. Spatial Analysis, 12, 515-546. https://doi. org/10.1007/s12061-018-9255-9

Schoorl, J. (1995). Fertility trends of immigrant populations. In S. Voets, J. Schoorl and B. de Bruijn (Eds.), The Demographic Consequences of International Migration (pp. 97-121). Proceedings of the symposium, NIAS, Wasenaar, 27-29 September 1990. Report No. 44, The Hague: NIDI.

Sobotka, T. (2008). Overview Chapter 7: The rising importance of migrants for childbearing in Europe. Demographic Research, 19(9), 225-248. https://doi.org/10.4054/DemRes.2008.19.9

Sobotka T. (2010). Les migrants exercent-ils une influence croissante sur la fécondité en Europe ?. Politiques sociales et familiales, 100, 41-59. https://doi.org/10.3406/caf.2010.2525 
Sobotka, T. (2017). Migrant Fertility in Europe: Accelerated Decline During the Great Recession Period?. Conference "The Fertility of Migrants and Minorities", Hannover (Germany).

Sobotka, T., Skirbekk, V., \& Philipov, D. (2011). Economic recession and fertility in the developed world. A literature review. Population and Development Review, 37(2), 267-306. https://doi.org/10.1111/ j.1728-4457.2011.00411.x

Sofianopoulou, L., \& Siapati, G. (2009). Fertility of Albanians in Albania and Greece at the beginning of the 21st century: A spatial approach (in Greek). In Proceedings of the 2nd Panhellenic Conference on Urban Planning, Spatial Planning and Regional Development, Volume III, (pp. 1405-1412). University Press of Thessaly, Volos. Retrieved from http://www.demography-lab.prd.uth.gr/SOFIANOPOULOU_ SIAPATI_2.pdf

Strozza, S., \& De Santis, G. (Eds.) (2017). Rapporto sulla popolazione. Le molte facce della presenza stranierain Italia. Bologna: il Mulino.

Strozza, S., Labadia, C., \& Ferrara, R. (2007). Il contributo delle donne straniere all'evoluzione recente della fecondità italiana. Rivista Italiana di Economia Demografia e Statistica, LXI(3-4), 419-428.

Testa, M.R., \& Stuart, B. (2012). Have lifetime fertility intentions declined during the Great Recession? Vienna Institute of Demography Working Papers, 9. Retrieved from https://www.econstor.eu/dspace/ bitstream/10419/96972/1/756764084.pdf

Tintori, G., \& Romei, V. (2017). Emigration from Italy After the Crisis: The Shortcomings of the Brain Drain Narrative. In J.M. Lafleur, \& M. Stanek (Eds.), South-North Migration of EU Citizens in Times of Crisis (pp. 49-64). IMISCOE Research Series. Springer, Cham. https://doi.org/10.1007/9783-31939763-4_4

Tønnessen, M., \& Wilson, B. (2020). Visualising Immigrant Fertility - Profiles of Childbearing and their Implications for Migration Research. Journal of International Migration and Integration. https:// doi. org/10.1007/s12134-020-00762-5

Tragaki, A., \& Bagavos, C. (2019). Fertility variations in the recession context: the case of Greece. Genus, 75, 18. https://doi.org/10.1186/s41118-019-0066-x

Tsimbos, C. (2008). Immigrant and native fertility in Greece: New estimates and population prospects (2005-2025). Population Review, 47(2), 67-84.

Vignoli, D., Tocchioni, V., \& Mattei, A. (2019). The impact of job uncertainty on first-birth postponement. Advances in Life Course Research. https://doi.org/10.1016/j.alcr.2019.100308

Vitali, A., \& Billari, F. C. (2017). Changing determinants of low fertility and diffusion: A spatial analysis for Italy. Population Space and Place, 23(2), e1998. https://doi.org/10.1002/psp.1998

Volant, S., Pison, G., \& Héran, Fr. (2019). French fertility is the highest in Europe. Because of its immigrants?. Population E Societies, 568.

UN, Department of Economic and Social Affairs Population Division (2019a). World Fertility data 2019. Retrieved from https://www.un.org/en/development/desa/population/publications/dataset/fertility/ wfd2019.asp

UN, Department of Economic and Social Affairs Population Division (2019b). World Population Prospects, Fertility estimates and projections, Fertility data. Retrieved from https://population.un.org/ wpp/Download/Standard/Fertility 